\title{
TRUE EU CITIZENSHIP AS A PRECURSOR TO GENUINE CRIMINAL JUSTICE IN EUROPE: AN ANALYSIS OF EU CITIZENSHIP AS IT RELATES TO A SUSTAINABLE AREA OF FREEDOM, SECURITY AND JUSTICE
}

\begin{abstract}
This paper traces developments - both legal and political in nature relating to EU citizenship and compares the status quo to what individuals might expect from citizenship particularly within the context of criminal proceedings. Drawing upon debates in political science, it highlights the divergence between EU citizenship and what would normally be associated with any idea of citizenship. Exploring the parameters of European criminal justice and its revolutionary direction of travel, this essay highlights how strongly exposed EU citizens are to enhanced coercive state power within criminal proceedings because of this status. Consequently it advances an argument that reasonable expectations of citizenship are set up to be disappointed in the current context. This is particularly true as the CJEU scales back the protections associated with EU citizenship in the face of political pressure. It argues that the loss of legitimacy the EU may suffer as a result affects not only its relationship to citizens. As the European institutions take action against democratically elected governments viewed as in breach of fundamental EU values, its potential as a policy-laundering governance level in the criminal justice arena is identified as an enormous legitimacy problem. Analysing developments relevant to citizenship from a criminal justice perspective, this paper demonstrates that reform is urgently required. Leaving EU citizenship in its current form - shaped by Executive powers - is argued to expose the EU to legitimacy arguments it cannot win, as well as individual citizens to injustice in criminal proceedings.
\end{abstract}

* Marianne L. Wade Birmingham Law School, University of Birmingham, Birmingham, UK. Email: m.l.wade@bham.ac.uk.

Reader in Criminal Justice at Birmingham Law School. I am grateful to my colleagues in the Global Law Group, Criminal Law and Evidence Reading Group and the Institute of European Law for their comments during conceptual discussion of this paper, as well as to Anthony Arnull for comments on an early draft. Special thanks are due also to Karen McAuliffe. Bence Leb and particularly Emma Marchant provided research assistance at various stages, for which I thank them. I am furthermore grateful to the KORSE at the University of Freiburg and Prof. Ralf Posher in particular; it was during the Fellowship they kindly provided me with in 2015 (with Brexit not yet a dreaded reality) that my work on this article began. I owe Dr Thomas Wahl thanks for highlighting that opportunity to me. 


\section{INTRODUCTION}

Citizenship is a concept born of revolution. In the modern era, it is a defining feature of modern liberal democracies and shapes central expectations of those living within them, of a balance struck between executive power and the liberty of individual citizens. These are constellations perhaps not immediately associated with the European Union, which is itself a forum of evolution: what began as a conglomeration of nation states bound only via economic ties now includes EU citizenship for all nationals of member states. Furthermore, the Area of Freedom Security and Justice (AFSJ) and its novel criminal justice mechanisms has become a central tenet of EU work, with the creation of a common European Public Prosecutor's Office (EPPO) for 22 member states forming the revolutionary cutting edge of this policy area. ${ }^{1}$

Scholarly discussion of EU Citizenship is well-established and multi-faceted. These debates, however, run along the lines of activity that the EU is more traditionally associated with, as we shall see. The uniform criticism of the AFSJ as unbalanced and frequently endangering citizens' liberties might suggest that EU citizenship must somehow be dislocated or disconnected from the AFSJ. Since the advent of the Treaty of Lisbon, however, it most decidedly is not (nor should it be, as this paper highlights).

This paper emphasises that the density of criminal justice provision at the EU level (i.e. for EU citizens), both legislative and institutional, is now so significant that it is reasonable to speak of EU citizens being exposed to certain criminal justice forms and mechanisms by virtue of that citizenship. This undeniably impacts upon core citizenship rights and matters. Via an exploration of the idea of citizenship and an analysis of what EU citizenship has come to mean, this article will demonstrate that the status quo is unsatisfactory, precisely because EU citizenship was not established with the needs of criminal justice in mind. Whilst acknowledging that EU citizenship requires novel concepts, recognising the differences between this supranational governance level and that of its member states, this paper calls for EU citizenship to be reformed to align with more conventional definitions. Given the significant value of criminal jus-

\footnotetext{
${ }^{1}$ Note the key value associated with security co-operation in Brexit negotiations. See Asthana et al., "Don't blackmail us over security, EU warns May" (30 March 2017) The Guardian, https://www.theguardian.com/politics/2017/mar/29/brexit-eucondemns-mays-blackmail-over-security-cooperation.
} 
tice mechanisms and institutions operating at the EU level, it is argued that EU citizenship must now urgently be adapted, to something more closely aligned with modern expectations and able to perform its vital tasks. The failure to re-conceptualise EU criminal justice measures at the heart of citizenship law has become unsustainable.

The key point is that the application of the constitutional principles embodied in notions of citizenship (of both individual member states and the EU itself) ${ }^{2}$ on former third-pillar matters (i.e. the AFSJ) is insufficient. The constitutionalisation of the EU has occurred in line with the freedoms it was providing, formed by an executive-dominated legislature committed to the notion that the EU should not wield power in terms of criminal justice. Whilst criminal justice usually resides at the core of constitutional systems as they develop, often embodying and expressing what the relevant constitution means, the way in which the EU has developed means it has impacted upon criminal justice matters as a corollary to economic enterprise and interests. This is not the way to construct robust constitutional structures from a criminal justice perspective. It is the framework within which EU citizenship has thus far been forged, however.

This paper argues that a failure to re-conceive EU citizenship appropriately endangers vital, fundamental rights of individual citizens. As Britain attempts to reassert the inter-governmental nature of EU criminal justice mechanisms, ${ }^{3}$ the fate of individuals unluckily caught by and subject to injustice will also fuel Euroscepticism and could undermine the legitimacy of the EU as a whole. As citizens rely on their EU rights to facilitate fundamentals such as where they chose to live, EU institutions strive to provide criminal justice and indeed to secure broader constitutional rights for all EU citizens, it is high time to overhaul the concept of EU citizenship to be truly worthy of the name.

\footnotetext{
${ }^{2}$ For example, the principles of proportionality (see Article 5 Consolidated Version of the Treaty of the European Union [2008] OJ C115/13 [TEU]) and nondiscrimination (Article 9 TEU).

${ }^{3}$ See HM Government, Security, Law Enforcement and Criminal Justice: A Future Partnership Paper (18 September 2017) available at: https://assets.publishing.service. gov.uk/government/uploads/system/uploads/attachment_data/file/645416/Secur ity_law_enforcement_and_criminal_justice_-_a_future_partnership_paper.PDF. The UK Government's Brexit security position ignores the need for anything but repressive criminal justice powers.
} 


\section{THE CONCEPT AND MEANING OF CITIZENSHIP}

Before any analysis of EU citizenship can take place, an understanding of the concept is required. Adopting any view of EU citizenship as atypical requires a clear notion of what citizenship usually entails. This is far from straightforward and no clear definition of citizenship exists. What citizenship entails and expectations associated with it, will furthermore vary from member state to member state across the Union. In order to provide a benchmark of the sort this article requires for the scrutiny of EU citizenship, key political science literature is explored.

The conception of citizenship is far from unitary. Definitions range from the more passive, liberal-individualist to the civic-republican conception of active, lived citizenship. ${ }^{4}$ It is important to note that citizenship is fundamentally recognised as a formal status associated with nation states. As such, it is also a concept that can exclude $^{5}$ : citizens belong, non-citizens do not. ${ }^{6}$ The core idea is that by virtue of membership of a polity, individuals as citizens have the ability to work to change to nature of that polity. Debates on the origin of ideas of citizenship abound, but it is clear that the concept crystallised in a certain form in ancient Greece, where it was associated with freedom for those fortunate enough to hold this status. It delineated a non-kinship-based relationship between individual and city and marked the citizen ${ }^{7}$ as free, rather than enslaved. Citizens fought alongside each other to maintain their citizenship and freedom in this sense. Their political institutions were organised to secure this freedom, including through compliance with the rule of law. ${ }^{8}$

In the modern era, citizenship is a child of the Enlightenment, associated with the emancipatory movements culminating in the

\footnotetext{
${ }^{4}$ In relation to the non-citizen, see David Taylor, Bryan Turner, Peter Hamilton (eds.) Citizenship: Critical Concepts (Routledge, 1994); J.G.A. Pocock, "The Ideal of Citizenship Since Classical Times" in Roland Beiner (ed.), Theorizing Citizenship (Albany, NJ: State University of New York Press, 1995) p. 29; Michael Ignatieff, "The Myth of Citizenship" in Beiner, Theorizing Citizenship, p. 54.

${ }^{5}$ In a modern invocation of arguments made by Locke and Kant (in relation to women and servants), Miller argues it must exclude to preserve the useful features of national identity, David Miller, On Nationality (OUP, 1997).

${ }^{6}$ See Taylor et al., supra note 5, pp. 36-37.

${ }^{7}$ Citizens were defined as male, adult and descended from locally-born parents.

${ }^{8}$ Geoffrey A. Hosking, Epochs of European Civilisation: Antiquity to Renaissance, Lecture 3. Ancient Greece, The Modern Scholar (Recorded Books, 2005).
} 
French and US American revolutions. ${ }^{9}$ Those contexts saw individuals who had been previously ruled become citizens, endowed with rights. This was demonstrated by the mass of legislation following these momentous events. The emergence of citizenship was not, however, necessarily dependent upon singular, declaratory events, and countries across Europe saw 'enlightened' rulers adopt key ideas such as codification, citizens' rights and the rule of law. ${ }^{10}$ Constitutions across Europe were formed and changed. Citizenship may be more concrete in jurisdictions in which it is associated with specific declarations (such as France) ${ }^{11}$ but it has naturally changed and developed over time. In jurisdictions such as England and Wales, where citizenship was introduced in a less dramatic way, ideas of citizenship determine everyday life.

As a status, however, citizenship is even more difficult to formally separate from that of nationality in such places. ${ }^{12}$ A key difference, however, is precisely that between a national and a citizen, lying in the citizen's right to elect those to whom power is given and indeed to stand for election herself. The core of citizenship is therefore a right to participate actively. ${ }^{13}$ Guillaume analyses varied approaches to citizenship as having an active component in common. He points to Isin's analysis that the vital feature of citizenship is its potential to alter the status and rituals that it entails. ${ }^{14} \mathrm{~A}$ citizen is an individual who can be active and who cannot be constrained from that activity except in very extreme circumstances (subject to the rule of law). The fundamental notion of citizenship is of each individual as bearing a constitutional status as a rights-holder, owed protections by every

\footnotetext{
${ }^{9}$ Rogers M. Smith, "Modern Citizenship", in Engin Isin and Bryan S. Turner (eds.), Handbook of Citizenship Studies (Sage, 2002).

${ }^{10}$ See for example the General State Laws for the Prussian States 1792 (Allgemeines Gesetzbuch für die Preußischen Staaten, AGB, 1792).

${ }^{11}$ See The Declaration of the Rights of Man and of the Citizen 1789 (Déclaration des Droits de l'homme et du Citoyen 1789).

${ }^{12}$ See UK Government, "Types of British Nationality" (2019) at https://www. gov.uk/types-of-british-nationality.

${ }^{13}$ Stefan Kadelbach, "Part V Citizenship Rights in Europe" in Dirk Ehlers (ed.), European Fundamental Rights and Freedoms (De Grueyter, 2007) pp. 547-548. On the notion of activity, note Plato's insistence that citizens must vote and be subject to punishment for failing to do so. Derek Heater, A Brief History of Citizenship (Edinburgh University Press, 2004) p. 1.

${ }^{14}$ Xavier Guillaume, "Regimes of Citizenship", in Engin Isin and Peter Nyers (eds.), Routledge Handbook of Global Citizenship Studies (Routledge, 2014) p. 153.
} 
governance level. A citizen is a person with the right to have rights. ${ }^{15}$ A number of responsibilities attach to this status, however. ${ }^{16} \mathrm{~A}$ citizen active within a polity is expected to adhere to its values. It is this form of polity that it has been argued the EU lacks. ${ }^{17}$

Citizens populate civil society, a 'third sphere of collective life'18 that Anantram et al. refer to as

an area of associative freedom; the freedom of individuals to enter into relations with others and pursue common purposes. The reference here is not to freedom per se, but the active exercise of freedom in forming networks of social relations... the basic idea behind "civil society" is maximization of associative freedom and minimization of coercion - by the state, political society, or the dominant class. ${ }^{19}$

Citizenship rights provide citizens with the ability to live their lives as they please and is therefore also to be associated with rights that go beyond human rights frameworks. In other words, citizens are more than mere rights-holders entitled to protect areas of their lives from governmental interference, but rather beings subject to the law and governing structures, ultimately with collective control over those very things. They can not only claim protection against the exercise of power but together alter how power is exercised altogether. For their status to remain coherent, logically this means that each individual's right to have rights must permeate every situation in which (governing) power is exercised.

\footnotetext{
${ }^{15}$ Isin and Nyers, supra note 14, pp. 18, 36 and 38, referencing Arendt (1966).

${ }^{16}$ In Ancient Athens, as in some modern jurisdictions, citizens were obliged to participate in the democratic processes to elect those populating governing structures.

${ }^{17}$ See Armin von Bogdandy, Gubernative Rechtsetzung. Eine Neubestimmung des Regierungssystems und der Rechtsetzung unter dem Grundgesetz in gemeineuropäischer Perspektive (A New Definition of Law-Making and the Governmental System under the Basic Law (Grundgesetz) in a Common European Legal System) (Mohr, 2000) p. 391. Dora Kostakopoulou, The Evolution of European Union Citizenship, European Political Science, 7, 2008, p. 287.

${ }^{18}$ Neera Chandhoke, "The Limits of Global Society", in Anheier Helmut, Marlies Glasius and Mary Kaldor (eds.), Global Civil Society 2001 (Oxford: Oxford University Press 2001) p. 36.

${ }^{19}$ Kadambari Anantram, Christopher Chase-Dunn, and Ellen Reece, "Global Civil Society and the World Social Forum" in Bryan S. Turner and Robert J. Holton (eds.), The Routledge International Handbook of Globalization Studies (Routledge, 2015) p. 557.
} 
Freedom from undue coercion by the state is therefore a key element of citizenship. Within the continuum of modern political theory and its translation into reality, the figure of the citizen represents each individual member of the (presumably powerless) masses asserting their right to stay the hand of an omnipotent executive in order to protect the core values of their lives. For the effective limitation of executive power, security from arbitrary punitive action is key. ${ }^{20}$ Thus movements advancing citizenship - such as the French Revolution - were followed by codification procedures ensuring the ambit of the criminal law was clear and that criminal procedures were subject to lawful bounds. ${ }^{21}$ Shaping the boundaries of criminal justice was urgently and intimately tied to the emergence of citizenship. As the ability to claim the status of citizenship status has become more important, so has the ability of individuals to insist upon freedom from state coercion. Citizenship is accompanied by an expectation of rights, of freedom and of transparency and accountability in the exercise of power. The increasing ability of each individual citizen to assert themselves can thus, for example, be traced through the limitation and then the prohibition of torture to extract confessions during the criminal process. ${ }^{22} \mathrm{~A}$ citizen endowed with dignity may not be treated in such a manner by their sovereign, nor by representatives of that sovereign in the form of (for example) agents of law enforcement, even when suspected of having committed a heinous

\footnotetext{
${ }^{20}$ Note that the reform of the criminal law and procedure was the subject of the "greatest activity" of the constituent and legislative assembly that followed the French Revolution of 1789. H.S. Sandford, The Different Systems: Penal Codes in Europe (Washington: Beverly Tucker Senate Printer, 1854) p. 9.

${ }^{21}$ See for example the Introduction to H.S. Sandford, supra note 20, but also the Expert Group on the Codification of Criminal Law, Codifying the Criminal Law (Dublin: Government Publications, 2004) para. 1.19 et seq. Note also the Expert Group's assertion at p. 5 that one of the "principle virtues of codification" includes "confirmation of the principle that, subject to the Constitution, the power to alter the parameters of the criminal law either by creating new offences or expanding the reach of existing ones rests exclusively with the legislature."

${ }^{22}$ See e.g. regulation of torture under Charles V: Georg Beyer, Ordnung des peinlichen Gerichts von Kayser Carolo den V. ...: mit einem Reg. aller darinnen enthaltenen Articul und Georg Beyers Vorbericht von denen Ursachen dieser neuen Aufflage (Leipzig: Braun, 1724). Detailed description of what torture was allowed in cases of how much evidence, as part of the Austrian Code in force until 1814 Freiburg Torture Museum, photo on file with author.
} 
crime. ${ }^{23}$ The modern notion of citizenship has fundamentally changed the relationship between the executive and individual citizens.

Whilst the concept of citizenship may elude clear definition, it is sufficiently concrete to enable practices to be deemed incompatible with modern ideas of citizenship. A further, vital feature is that this is not a theoretical concept, but rather one that relates to and shapes the experiences and expectations of individuals. As Tonkiss argues, in order to be meaningful, citizenship must also be felt in the local. ${ }^{24}$ For the purposes of this paper, this means it must be noticeable in every decision that affects the legal position of an individual. It must certainly be in play (and effectively so) when coercive, punitive powers are exercised against citizens. As we shall see, this is not true of EU citizenship as currently constituted.

Modern citizenship should, thus, shape the forms and expectations of criminal justice decisively. The latter constitutes a particularly sensitive policy area giving expression to the delicate relationship between sovereign and the citizen. Criminal law and in particular the protections of criminal procedure (bearing out constitutional values e.g. via the need for warrants) are specific and core expressions of what it means to be a citizen. The criminal law may be characterised as the strongest expression of civic responsibility and the protections of criminal procedure an expression of the enduring nature of citizenship (sufficiently durable to shape processes even when they are responding to a breach of responsibility). This is, however, a controversial balance, often in a state of constant reform. ${ }^{25}$ The precise balance of accountability a citizen owes to their community, and how far they can defend themselves against state power enforcing collective norms, is thus subject to continual modification.

Nevertheless, criminal justice consistently encompasses the area of law by which sovereign executives can intervene in the lives of their citizens most intimately. As Simester, Spencer, Sullivan and Virgo state, 'criminal law is the means by which the State forces citizens into

${ }^{23}$ See for example the concept of human dignity codified in Article 1 of the German Constitution (Grundgesetz) at https://www.bundesregierung.de/breg-en/ chancellor/basic-law-470510.

${ }^{24}$ Katherine E. Tonkiss "Experiences of EU citizenship at the sub-national level" in Isin and Nyers, supra note 14.

${ }^{25}$ Nigel Morris, "More than 3600 new offences under Labour" (4 September 2008) The Independent at https://www.independent.co.uk/news/uk/home-news/morethan-3600-new-offences-under-labour-918053.html. 
complying with its injunctions. ${ }^{26}$ Criminal justice measures provide states with means by which they can deprive individuals of their property, their liberty, their citizenship rights (and indeed citizenship itself in extreme and controversial cases). ${ }^{27}$ The criminal law (so the cliché goes) delineates the most intimate values of a community. Those who break the criminal law are stigmatised as having breached those values; ${ }^{28}$ they have let down the polity in which they live. They are required, under the strongest force of law, to make amends in order to enjoy their citizenship fully again. The punishments of criminal law place limits on citizenship in various forms. ${ }^{29}$ Traditionally, however, modern criminal law involves punishment within a community. The most extreme form (incarceration) contains an element of removal from the community (the central point, after all, is incapacitation. Additional measures, such as the removal of citizenship rights such as that to vote, further underline the removal from a community) but with rehabilitation and reintegration usually intended (supported by visitation rights, open prisons, facilitation of employment upon release, etc.). ${ }^{30}$ Even the most severe punishment of citizens will not entirely strip away the core features of their lives (prisoners will, for example, be located as close as possible to children to facilitate visits. Convicts are no longer banished to another continent). The fundamental nature of modern, liberal criminal justice systems is that executive power is strongly regulated and (so the theory suggests) stringently limited by law. ${ }^{31}$ Viewed through the lens of citizenship, criminal justice provisions lend specific contours to the balance of the relationship between ruler and ruled.

${ }^{26}$ A.P. Simester, J.R. Spencer, G.R. Sullivan, G.J. Virgo, Simester and Sullivan's Criminal Law: Theory and Doctrine (Oxford: Hart Publishing 5th edn., 2013) p. 6.

${ }^{27}$ See European Parliamentary Research Service, The Return of Foreign Fighters to European Soil: Ex-post Evaluation (2018) p. 82 et seq.

${ }^{28}$ See e.g. C-145/09 Land Baden-Württemberg v Panagiotis Tsakourisdis [2010] ECR I-11979; also discussed in Elspeth Guild, "European Union citizenship rights and duties: civil, political, and social" in Isin and Nyers, supra note 14, p. 422.

${ }^{29}$ Incarceration, the loss of rights to vote, stand for election, etc. For a European overview see Milena Tripkovic, Punishment and Citizenship (Oxford: Oxford University Press, 2019).

${ }^{30}$ See e.g. Sally Kyd, Tracey Elliott and Mark A. Walters, Clarkson and Keating Criminal Law: Text and Materials (Sweet and Maxwell, 9th edn., 2017)p. 5; and set out as the purpose of incarceration in Article 2 of the German Prison Act (Strafvollzugsgesetz, StVollzG) at: https://www.gesetze-im-internet.de/stvollzg/_2. html.

${ }^{31}$ See Sandford, supra note 20; and Expert Group on Codification, supra note 21. 


\section{CITIZENSHIP AND THE EUROPEAN UNION}

If citizenship is tied, via the concept of civil society, to an idea of associative freedom, then the European Union is of clear relevance to any discussion of it. As a supra-national governance level providing for the free movement of people, goods, capital and services at the heart of its activities, it clearly advances the capacities of individuals affected by the freedoms it grants. ${ }^{32}$ It is not difficult to imagine EU freedoms forming the basis of many individuals' notions of civil society and thus the very basis upon which they live their lives.

\subsection{EU citizenship}

Since the Treaty of Maastricht, the EU Treaties also expressly provide for citizenship rights, creating European Union citizenship. Citizenship of the EU has always been an oddity, legislated for after negotiations within the Council of the EU. ${ }^{33}$ This is unusual because the members of the Council are exclusively members of the executives of their respective member states. They may be interpreted as acting in the tradition of enlightened European rulers but (uniquely) neither the Council nor EU citizenship was created in response to an overwhelming social force with corresponding scrutiny. This is noteworthy because it means the concept of EU citizenship was created by the very level of government against which citizenship usually acts as a counterweight. The deficient way in which EU citizenship was created marks it to this day and renders it unable to fully perform the functions it must, as defined by this paper.

EU citizenship relates to freedoms that are doubtlessly important to those who exercise them. However, it is entirely contingent, existing solely as a result of nationality of a member state. ${ }^{34}$ It lends meaningful expression to the special status of the liberties it relates to (those associated with the four freedoms), but it is, fundamentally, a different kind of citizenship, born of the circumstances of its particular "community." The key oddity for the purposes of this paper is

\footnotetext{
${ }^{32}$ See Catherine Bernard, The Substantive Law of the European Union: The Four Freedoms (Oxford: Oxford University Press, 6th edn., 2019).

${ }^{33}$ The European Council and the Council of the European Union consist entirely of ministers from member state governments, in other words members of diverse national executives. See European Union, "European Council" at https://europa.eu/ european-union/about-eu/institutions-bodies/european-council_en.

${ }^{34}$ European Union, "EU Citizenship" at https://europa.eu/european-union/ about-eu/eu-citizenship_en.
} 
that EU citizenship was not created or defined with criminal justice in mind. Until the Treaty of Lisbon (which came into force some sixteen years later), criminal justice was simply not viewed as a proper EU matter. From its legislative starting point, ${ }^{35}$ the Area of Freedom Security and Justice (AFSJ) was a "special area" of law reserved for executive action due to the inter-governmental nature of the former Third Pillar. ${ }^{36}$ Whilst structures and organs of the EU were utilised to criminal justice ends, these were very deliberately characterised as serving the member states whose executives happened to be choosing this forum. Criminal justice purposes were expressly catered for as different, with legislative measures based upon mutual recognition rather than more traditional EU approaches (harmonisation). ${ }^{37}$ This was done precisely to demarcate criminal justice matters as reserved for the exercise of sovereignty by the member states. ${ }^{38}$

As it was not a "proper" EU matter, criminal justice was not deemed to require consideration when EU citizenship was discussed. Generally speaking, member states have resisted the overt constitutionalisation of the EU in a manner that has allowed criminal justice to take up its usual, central place (as measured by the domestic setups within the EU). ${ }^{39}$ Consequently, the idea of EU citizenship

${ }^{35}$ Interestingly perhaps, also the Maastricht Treaty, Treaty on European Union (Maastricht Treaty) [1992] OJ C 191, at https://eur-lex.europa.eu/legal-content/EN/ TXT/HTML/?uri = LEGISSUM:xy0026\&from $=$ EN.

${ }^{36}$ On the pre-Lisbon structure of the EU see Steve Peers, EU Justice and Home Affairs Law (Oxford: Oxford University Press, 3rd edn., 2011) p. 5 et seq.

${ }^{37}$ See European Council, Presidency Conclusions: Tampere European Council 15th and 16th October 1999, at: http://www.europarl.europa.eu/summits/tam_en. htm?textMode $=$ on. This came as a British initiative i.e. noticeably at the behest of a member state most vehemently opposed to the citizenship notion at the EU level and one in which citizenship rights are not expressed as strongly as in others, due to the lack of a written constitution.

${ }^{38}$ See Jack Straw's evidence to House of Lords Select Committee on the European Union, UK Parliament, Prospects for the Tampere Special European Council (HMSO, 27 July 1999) European Communities Select Committee, Nineteenth Report, para. 19, at: https://publications.parliament.uk/pa/ld199899/ldselect/ldeucom/ 101/10104.htm.

${ }^{39}$ See e.g. the failed Constitutional Convention and the fate of the Treaty of Nice, later adapted, stripped of many constitutional features into the Treaty of Lisbon. Kaarlo Tuori, "The Failure of the EU's Constitutional Project" (2007) 3 No Foundation: An Interdisciplinary Journal of Law and Justice, 37-48; Willem Maas, "The Origins, Evolution and Political Objectives of EU Citizenship" German Law Journal, $15 / 05$, p. $797-820$. 
developed without the central relationship to criminal justice matters usually found in national settings.

Challenges arise, however, because life is not divisible into clean categories. As Kostakpopoulou observes, citizenship restricted to the mercantile is a very strange reflection of what a citizen is. ${ }^{40}$ EU citizenship endows rights fundamental to the way many people choose to live. Any attempt to restrict EU citizenship to particular areas of human activity ignores modern understandings of behaviour, such as the criminological truth that "crime is normal." ${ }^{41}$ Where there are people, there will be crime. Citizens across Europe expect a state response to crime (producing criminal justice), which thus needs to move in the same realms as people and cannot be artificially contained. Unsurprisingly, criminal justice matters have arisen at the EU level as a corollary of the freedom of movement of persons ${ }^{42}$ and other core policy areas. ${ }^{43}$ The member states also utilise the forum of the EU to criminal justice ends. ${ }^{44}$ Therefore, the AFSJ (i.e. criminal justice matters within the EU) has become more significant.

The key point in relation to EU citizenship, however, is that it has evolved marked by the original fiction that it bore no relation to criminal justice. Consequently, the application of the constitutional principles (of both member states and the EU) on former Third Pillar matters is insufficient. The constitutionalisation of the EU has occurred in line with the freedoms it was providing, formed by a(n executive-dominated) legislature committed to the EU as a governance level without criminal justice powers criminal justice (as defined by the Council). Whilst criminal justice usually rests at the core of, and gives meaning to, constitutional systems as they develop, the development of the EU has impacted upon such matters as a corollary to economic enterprise and interests, or as a result of ad hoc

\footnotetext{
${ }^{40}$ Dora Kostakopoulou, "European Union Citizenship Rights and Duties" in Isin and Nyers, supra note 14, p. 428.

${ }^{41}$ Emilie Durkheim, "Rules for the Distinction of the Normal from the Pathological" in S. Luke (ed.) The Rules of Sociological Method (London: Palgrave, 1982).

${ }^{42}$ See C-123/08 Dominic Wolzenburg [2009] ECR I-09621; C-66/08 Szymon Kozowski [2008] ECR I-06041, also discussed below.

${ }^{43}$ See Environmental Law Case, C-173/03 Traghetti del Mediterraneo SpA v Repubblica Italiana [2006] ECR I-05177; and Ship-Source Pollution, C-440/05 Commission of the European Communities v Council of the European Union [2007] ECR I-09097.

${ }^{44}$ Hence the inter-governmental nature of the Third Pillar. See Andre Klip, European Criminal Law (Intersentia, 1st edn., 2009).
} 
(executive) political will. Attention was thus not paid to their constitutional significance. This is not a viable way to create a robust framework for citizenship from a criminal justice perspective.

Without such holistic robustness, EU citizenship is rendered far more malleable than any modern notion of citizenship in the member states would suggest. Citizens' expectations are, however, principally based upon national norms and thus there are significant consequences when the truth of EU citizenship is exposed, as can be seen in the horrified exasperation of British citizens living in other member states $^{45}$ upon discovering that such rights can be withdrawn via a simple Act of Parliament (after a guiding democratic vote from which they were excluded). ${ }^{46}$ This also demonstrates that member state executives perceive EU citizenship as something they can grant and take away at will ${ }^{47}$. If one compares this to the ideas of citizenship outlined in section 2, one must conclude that EU citizenship lacks key features usually associated with the concept. In relation to criminal justice matters, the "Justice in Europe" campaign of Fair Trials International (and the way in which case examples have been integrated into Eurosceptic arguments $)^{48}$ highlights that EU criminal

${ }^{45}$ This also led to litigation e.g. in Dutch courts, see Netherlands Ministry of Foreign Affairs and others $v$ Stichting Brexpats - Hear Our Voice and others (De Staat der Nederlanden: Ministerie van Buitenlandse Zaken and De Gemeente Amsterdam v Stichting Brexpats - Hear our Voice and others) [2018] NJ 2018/460 https://uit spraken.rechtspraak.nl/inziendocument?id = ECLI:NL:GHAMS:2018:2009; and, "Dutch Judges refer British Expats case to top European Court" (17 February 2018) Deutsche Welle, https://www.dw.com/en/dutch-judges-refer-british-expats-eur opean-citizenship-case-to-top-eu-court/a-42491751.

${ }^{46}$ See UK Government, "Types of Election, Referendums, and who can vote" https://www.gov.uk/elections-in-the-uk/referendums for voting rules. From a legal point of view it is interesting that this group of British citizens were excluded from the vote, presumably on the grounds that they did not reside in the UK, while EU nationals that had exercised their EU right to move to the UK were excluded on the basis of nationality.

${ }^{47}$ Amply illustrated for example by the need for reciprocal agreements to ensure other member state nationals living in the UK are to be allowed to remain post Brexit. See Ros Taylor "Logically Flawed, Morally Indefensible" (16 February 2017) LSE Blog, https://blogs.1se.ac.uk/brexit/2017/02/16/logically-flawed-mor allyindefensible-eu-citizens-in-the-uk-are-bargaining-chips/

${ }^{48}$ See Fair Trials, "Justice in Europe" at https://www.fairtrials.org/campaign/ justice-europe and e.g. Nigel Farage, "Why Did Nick Clegg keep Ducking the Vital Questions in Our Debate Last Night?" (27 March 2014) The Independent, https:// www.independent.co.uk/voices/comment/nigel-farage-why-did-nick-clegg-keepducking-the-vital-questions-in-our-debate-last-night-9218519.html. 
justice mechanisms can be utilised in manners deeply at odds with any public notion of justice.

In other words, for those creating them, EU rights may be regarded as an add-on, whereas for citizens (i.e. rights-holders), EU rights may form the foundation of how citizens live their lives and form associations. Where an EU citizen lives, how they politically engage, etc. can be entirely dependent upon the freedom of movement granted by the EU. EU rights thus provide individuals with options to fundamentally order the framework of their citizenship. For example, an Irish national can live in Germany and immediately exercise her right to vote in EU elections there. The longer she lives in Germany, the better she will likely become established in the community. Utilising her EU rights, she may reside for long enough to become entitled to German citizenship and therewith to become fully active within that polity. EU citizenship bears the potential to widen and indeed entirely alter individual horizons. It enables a citizen to wholly redefine their community and civil society. A citizen's sense of the local may be entirely dependent upon rights gained via what the member states have labelled EU citizenship. Further, that label matters; citizenship is not about a top-down perspective and what may seem acceptable from that point of view. As highlighted above, it must be felt in the local and by the individual to truly have meaning. Tension between member state development and EU rights doubtlessly mark (and hugely complicate) the development of EU citizenship. The multi-level governance structures of the EU mean citizenship of it must evolve in a novel way. They also, however, urgently necessitate a robust form as the status quo all too often highlights.

Clearly, EU citizens have clear expectations of the rights and freedoms granted to them by that status. Unsurprisingly therefore, the EU, as a governance level espousing the idea of citizenship, has been called upon to fulfil the promise of that concept. Those called upon to review scenarios in which EU citizenship rights appear threatened have demonstrated their own understanding of EU citizenship, decisively marked by more conventional understandings of citizenship. As the next sections will demonstrate, significant efforts have been made to interpret the relevant law to render it meaningful, but again such efforts have been hampered by fundamental deficiencies in the nature of EU citizenship.

Because the idea of EU citizenship raises legitimate expectations on the part of citizens and because the EU intervenes in core areas of 
citizens' lives, it is imperative that all parties are working with the same understanding of what citizenship denotes. To exclude policy areas marked by citizenship rights in member states is to open those up as policy-laundering opportunities i.e. using the EU (as a governance level) to undermine protections owed to citizens within nation states. Whilst one must recognise that member state governments are sometimes tempted to act in such a manner, it unquestionably bears acute danger for the EU. If the EU facilitates hard-won liberties being undermined, it provides fuel for demands that the EU be dismantled.

\subsection{EU citizenship and the CJEU}

The Court of Justice of the European Union (CJEU) is the forum in which arguments highlighting the tension caused in EU citizenship matters by the divergence between citizens' expectations and reality most readily arise. From a citizenship perspective, seminal cases like the Factortame litigation ${ }^{49}$ look like conventional demands of citizens staying the hands of sovereigns to secure their rights (in that case, freedom of movement). The judiciary are called upon, for example to prevent executives from removing non-nationals from their territory. ${ }^{50}$

As Kostakpopoulou notes, challenges put before the CJEU ultimately resulted from the unsustainable nature of EU citizenship as purely mercantile. ${ }^{51}$ The idea of EU citizenship advanced in the Treaties seemingly assumed that individuals are able to separate their professional and personal beings. ${ }^{52}$ This was citizenship shaped by the political reality of what the member states (as represented in the Council) would accept. ${ }^{53}$ Unsurprisingly, however, as EU citizenship

${ }^{49}$ C-213/89 R (Factortame Ltd) v Secretary of State for Transport [1990] ECR I02433; C-221/89 [1991] ECR I-03905; C-46/93[1996] ECR I-01029.

${ }^{50}$ Thus, Factortame not only asserted the supremacy of EU law but also stayed the hand of the British executive to secure the EU freedoms of EU citizens. See Catherine Baksi, "Landmarks in the Law: The 90s Fishing Case that Stoked UK Euroscepticism" (29 March 2019) The Guardian, https://www.theguardian.com/law/ 2019/mar/29/landmarks-in-law-the-90s-fishing-case-that-stoked-uk-euroscepticism.

${ }^{51}$ Kostakopoulou, supra, note 18, p. 286; Willem Maas, "European Union Citizenship in Retrospect and Prospect" in Isin and Nyers, supra note 14, p. 428.

${ }^{52}$ As Kostakopoulou also highlights, EU bodies never proposed EU citizenship in this manner. Dora Kostakopoulou, "European Union Citizenship Rights and Duties" in Isin and Nyers, supra note 14.

${ }^{53}$ See also Maas, supra note 52, p. 415. 
rights affected more lives, laws drafted with this in mind came to be questioned and also came before the CJEU. Through its interpretation and application of the law, the stature of EU citizenship grew.

The ambit of the CJEU's consideration of EU citizenship was predetermined by the specific form envisaged by the member states. The CJEU spoke to citizenship issues where an application of EU law was at stake. As legal complications became more apparent, however, the designation of only certain areas as relevant for consideration could not hold up in the real world. The high-water mark of Ruiz Zambrano saw the Court establish that any measures that 'have the effect of depriving citizens of the Union of the genuine enjoyment of the substance of the rights conferred by virtue of their status as citizens of the Union' will be regarded as falling within the ambit of EU law. ${ }^{54}$ EU citizenship became established as 'independent of economic status,' the tie to economic activity only having proved unsustainable. Decades of jurisprudence led to the establishment of a more holistic legal status, recognised by (non-criminal justice) commentators as 'true citizenship'. 5 '

This line of CJEU jurisprudence provided an open and interesting concept of EU citizenship as an independent notion, which could then become the foundation of a more complete institution and which might plausibly protect rights, also within the AFSJ context. For example, there is now ample evidence that citizens being subject to court decisions in a country other than that in which they reside will almost certainly be detained, as they are deemed to pose a higher flight risk. ${ }^{56}$ This will normally be the case when citizens are arraigned for trial following surrender via the European Arrest Warrant (EAW) ${ }^{57}$ In other words, the special measures available for use against EU citizens in the criminal justice arena expose them to a higher probability of pre-trial detention. In terms of the enjoyment of citizenship rights, the detrimental effects of detention are clearly all

${ }^{54}$ C-34/09 Ruiz Zambrano v Office National de L'emploi [2011] ECR I-01177; C135/08 Janko Rottman v Freistaat Bayern [2010] ECR I-01449; and C-434/09 Shirley McCarthy v Secretary of State for the Home Department [2011] ECR I-03375.

${ }^{55}$ See Dimitry Kochenov, and Sir Richard Plender, "EU Citizenship: From Incipient Form to an Incipient Substance?” (2012) 37 E. L. Rev., 369-396, 393.

${ }^{56}$ Fair Trials International, A Measure of Last Resort? The Practice of Pre-trial Detention Decision-Making in the EU (May 2016) p.7. https://www.fairtrials.org/ publication/measure-last-resort.

${ }^{57}$ The key instrument of the AFSJ was created by Council Framework Decision 2002/584/JHA of 13 June 2002 on the European Arrest Warrant and the Surrender Procedures between Member States OJ L 190, pp. 1-20. 
the more devastating if an individual is subject to detention far away from their families. ${ }^{58}$ Detention without ordinary visitation possibilities (known to be of great import to detainees and their prospects) could consequently be construed as interfering with the full enjoyment of freedom of movement. The CJEU might have been expected to engage with criminal justice matters following the logic of its Ruiz Zambrano case-law. There was legal potential for the CJEU to bring the AFSJ into citizenship jurisprudence via a broad interpretation of what a full enjoyment of rights could mean. Criminal justice scholars might hesitate to endorse this path, but it had legal potential.

The Court has demonstrated its ability to champion citizens' rights in a variety of contexts. The assertive stance taken by the Court in the Schrems case demonstrated that it can act a forum for more holistic rights protection. ${ }^{59}$ That case saw the CJEU declare that national data protection structures may examine and raise concerns about standard contract clauses (SCCs) used to transfer data to third states without data protection regimes deemed equivalent to those of the EU, but only the CJEU can assess such regimes. The Court appeared eager to follow its own case-law through to prevent loopholes. Schrems I saw the Safe Harbour framework struck down as a basis for data exchange with the US, as no satisfactory system of redress was available and exchange on the basis of SCCs became standard operating procedure (these impose contractual obligations upon parties to ensure adequate data protection). Kadi can also be viewed as a case of the CJEU tempering the executive power of EU legislation. ${ }^{60}$

The CJEU's development of EU citizenship culminating in the Ruiz Zambrano line of jurisprudence has, however, been halted. Any hopes for comprehensive rights protection in the AFSJ pinned on it must be abandoned. Member state displeasure with the notion of EU citizenship being furthered by the CJEU came to a head in the case of

\footnotetext{
${ }^{58}$ Even where implementation of Measure A (the Right to Interpretation and Translation) of the Stockholm Programme is perfect, this has an enormous impact upon the individual. See Justicia, "Procedural Rights: Right to Interpretation and Translation (Measure A), at http://eujusticia.net/index.php/proceduralrights/cate gory/right-to-interpretation-and-translation-measure-a/.

${ }^{59}$ C-362/14 Maximillian Schrems $v$ Data Protection Commissioner [2015] ECLI:EU:C:2015:650.

${ }^{60}$ Joined Cases C-402/05 P and C-415/05 P Yassin Abdullah Kadi and Al Barakaat International Foundationv Council of the European Union and Commission of the European Communities, [2008] ECR I-06351.
} 
Commission v UK. ${ }^{61}$. Although the Court never overtly refers to it as a citizenship case, it undeniably highlights the core problem with EU citizenship. The court was confronted by a matter clearly impacting upon citizenship, as it was asked to decide whether the UK had the right to insist upon a child having the legal right to reside in the country before receiving child benefit, or whether this would breach freedom of movement rights of EU nationals. The Commission asserted that the UK Government had imposed a condition additional to those outlined in Regulation No 883/2004 and was thereby discriminating against EU citizens (because the criterion is one that UK nationals automatically meet) from other member states legitimately exercising their freedom of movement rights. The Commission underlined that the purpose of the Regulation providing for the coordination of social security systems is to encourage freedom of movement, whilst the UK set-up was designed to discourage it. ${ }^{62}$ The Court, however, interpreted the Regulation as allowing member state discretion in determining the conditions of access to social security benefits ${ }^{63}$ for the economically inactive and thereby ruled that a right to reside requirement fell within the scope of that discretion. ${ }^{64}$ The Court furthermore chose to accept the UK's assertion that powers were not exercised in a discriminatory manner and made clear ${ }^{65}$ that the Commission must demonstrate the discriminatory nature of such provisions to trigger protective Court intervention. This point is a key concern from the perspective of citizenship rights. The Court defers to an executive, accepting a simple statement of non-discrimination. Furthermore, the reversal of the burden of proof involved in demanding that the Commission establish facts of discrimination, rather than the UK (as the holder of such documentation) being required to demonstrate that no discrimination is taking place, is anything but a robust defence of citizenship rights. The principle of non-discrimination is a fundamental of EU law. ${ }^{66}$ The abandonment of effective citizenship protection is further highlighted by the Court's failure to examine the proportionality of the measure. The propor-

${ }^{61}$ C-308/14 European Commission v United Kingdom of Great Britain and Northern Ireland [2016] ECLI:EU:C:2016:436.

62 Ibid, para. 45.

63 Ibid, para. 67.

${ }^{64}$ Ibid, para. 68.

${ }^{65}$ Ibid, para. 85.

${ }^{66}$ Codified in Article 9 TEU. 
tionality principle has consistently been a core touchstone of CJEU scrutiny and that the court should shy away from it when such defining questions are involved is startling. ${ }^{67}$

This case is viewed as dismantling the advances made in EU citizenship law. Nic Shuibhne ${ }^{68}$ speaks of secondary law being given supremacy over primary law to the point of overruling constitutional fundamentals. In particular, the citizenship of the children concerned (who should ultimately benefit from the child benefit and child tax credits at stake) is entirely ignored. The case has been analysed as 'eviscerating' the concept of citizenship ${ }^{69}$ and was one of a series of cases limiting EU citizenship for the "economically inactive. ${ }^{70}$ It counteracted the Ruiz Zambrano line in which development of EU citizenship was perhaps adhering to more conventional understanding of citizenship and in which CJEU judges used their understanding of the concept of citizenship to declare that the principles of EU law applied to all EU citizens. In so doing, they seemingly abandoned the CJEU interpretation of citizenship upon which criminal justice scholars might have pinned more conventional expectations (because the abandoned interpretation provided legal footholds for e.g. procedural rights) upon within established EU parameters.

It is particularly concerning to note the apparent lack of concern for non-discrimination in this case. The nature of citizenship is that states cannot simply disown errant citizens. European constitutions have undergone considerable change precisely to limit executive powers that might allow a state to banish or execute its nationals. Therefore, the threat of deportation applies only to non-nationals. The Court might even be accused of rushing to empty EU fundamental rights of any such constitutional value because they ignore the central point, which is that they are allowing member states to utilise a mechanism that can only be mobilised to the detriment of some (non-national) EU citizens, meaning the issue of discrimination is raised.

${ }^{67}$ See W. Sauter, "Proportionality in EU Law: A Balancing Act?" (2013) 15 Cambridge Yearbook of European Legal Studies 439-466.

${ }^{68}$ N.N. Schuibhne, "Limits Rising, Duties Ascending: The Changing Legal Shape of Union Citizenship" (2015) 52 Common Market Law Review 889-938.

${ }^{69}$ C. O’Brian, "ECJ Sacrifices EU Citizenship in Vain” (2017) 1 CMLR 209-243.

${ }^{70}$ C-333/13 Elisabeta Dano and Forin Dano $v$ Jobcenter Leipzig [2014] EU:C:2014:341; C-67/14 Jobcenter Berlin Neuköloin v Nazifa Alimanovic and Others [2015] ECLI:EU:C:2015:210; C-299/14 Vestische Arbeit Jobcenter Kreis Recklinghausen v Jovanna Garcia-Nieto and Others [2016] ECLI:EU:C:2015:366. 
Thereafter, in the $\mathrm{PI}^{71}$ case, the Court (decided not to follow A.G. Bot's Opinion and instead) seemingly ascribed member states the discretion to decide which crimes breach fundamental values and pose a security threat, precisely because no proportionality test was demanded. ${ }^{72}$ The court's failure to restrict its evaluation to serious crimes means any criminal conduct can demonstrate the requisite lack of integration, providing executives with tools to discriminate between criminals and to rid themselves of convicts, even where this may be harmful to their rehabilitation and reintegration. ${ }^{73}$ Citizens will reasonably ask how this can be reconciled with principles such as the requirement of non-discrimination, which they expect the EU to uphold as a fundamental value. Freedom of movement rights not associated with any protection of family life (as soon as a member is convicted) cannot but be devalued in the eyes of their bearers. As Mitsilegas analyses, the PI judgment elevates (at least) crimes mentioned by the member states in the Treaty (article 83) to a status such that they can weaken citizenship protections. ${ }^{74}$ This demonstrates the fragile nature of EU citizenship: citizenship should protect rights precisely when the instinct for executive overreach is strongest.

Furthermore, the Commission v UK case highlights the core problem with EU citizenship, exposing the CJEU as far from independent of the circumstances in which it operates. Commentators speak of the CJEU sacrificing the concept of EU citizenship under pressure from the imminent UK referendum. ${ }^{75}$ The Court was faced with political sensitivity and pressure of the greatest kind and it buckled despite the substantive issue being citizenship. It could be argued that it was only able to do so because the law of EU citizenship (as shaped by the Council) lacks sufficient strength to support a court in doing anything else. For citizenship rights to be meaningful, they cannot be vulnerable to pressure from a single national executive or political event. A judicature must be equipped (by the

\footnotetext{
${ }^{71}$ C-348/09 P.I. $\quad v \quad$ Oberbürgermeisterin der Stadt Remscheid [2012] ECLI:EU:C:2012:300.

${ }^{72}$ This has been criticised as the court turning a protection against deportation into a means to facilitate it. See Leandro Mancano, "Criminal Conduct and Lack of Integration into the Society under EU Citizenship: This Marriage is Not to Be Performed" (2015) 6(1) New Journal of European Criminal Law, 53-77.

${ }^{73}$ See also Valsamis Mitsilegas, EU Criminal Law after Lisbon (Hart, 2016) pp. 231-232.

${ }^{74}$ Mitsilegas, supra note 69, p. 233.

75 See O’Brian, supra note 65.
} 
law) to hold its ground against an executive, in the name of the citizens endowed with the rights concerned.

Thus, the CJEU (an erstwhile champion of a more holistic notion of EU citizenship) has shown itself to be hampered by the mercantile nature of the concept when under pressure. Further, more recent cases must be viewed as shutting the door on what CJEU jurisprudence had indicated as a possible route to citizenship and criminal justice relating to each other at the EU level in a more conventional manner. They represent an institution of citizenship marked by the limits executives ${ }^{76}$ wish to set: precisely what citizenship should not be. A citizen must be able to rely on her rights precisely when the executive wishes to deprive her of them. This has also been highlighted as the weakness of citizenship law by cases (like PI) of EU citizens settled in another member state who have objected to being deported following a conviction. ${ }^{77}$ Far from accepting that crime is normal (and that citizens commit crime), many member states argue that a non-national EU citizen who commits a crime has demonstrated their failure to integrate. ${ }^{78}$ This notion of criminal activity (the opposite of even petty 'crime [a]s normal') propagated by the Council is in part accepted by the CJEU in criminal justice matters, undermining the constitutional nature of the EU citizenship rights being utilised. Reasonable expectations of citizens are thereby not met, likely causing them to lose faith in the EU.

\footnotetext{
${ }^{76}$ Member states also logged arguments before the Court in these cases (eight were represented in PI, for example).

77 See C-378/12 Nnamdi Onuekwere v Secretary of State for the Home Department [2014] EU:C:2014:13; and C-348/09 P.I. v Oberbürgermeisterin der Stadt Remscheid [2012] EU:C:2012:300.

${ }^{78}$ See A.G. Bot's Opinion of 3rd October 2013 for C-378/12, supra note 73, para. 50, followed by Court. See also Mancano, supra note 68, p. 66 et seq. This is also the much-criticized aspect of A.G. Bot's opinion in PI delivered on 6th March 2012: see Georgios Anagnostaras, "Enhanced Protection of EU Nationals Against Expulsion and the Concept of Internal Public Security: Comment on the PI Case (Case Comment)" (2012) 37(5) E.L. Rev. 627-639; and Dimitry Kochenov and Benedikt Pirker, "Deporting the Citizens within the European Union: A Counter-Intuitive Trend in Case C-348/09, P.I. v. Overbürgemeisterin der Stadt Remscheid" (2013) 19 Columbia Journal of European Law 369-390, 384-386, Mistilegas, supra note 69, p. 229. Note that alongside the Commission, Germany argued against this blanket assumption, saying that it should only apply when such a breach demonstrated disregard for values (so arguing for proportionality, which would have limited the damaging impact that a short-term sanction and/or less serious conviction might have).
} 
Judgments such as these ensure that EU citizenship remains deferential. ${ }^{79}$ Citizens are granted freedoms to reside in member states of their choosing but even a lengthy period of legal residence will not preclude the host countries' right to expel such a citizen upon conviction. ${ }^{80}$ So, EU citizenship is only tentative, not providing surety in associative freedom. It appears to be rather a stratified notion of rights, to which only the virtuous (as deemed by the relevant national executives) ${ }^{81}$ are entitled. This undermines the very core of citizenship, at the heart of which lies the notion that it is not for the executive to limit the fundamentals of life. A citizen can and must be held responsible for her actions within a community but her membership of that community is protected from arbitrary or discriminatory action by the executive. ${ }^{82}$

Ultimately the CJEU can only operate within the bounds established in law. It cannot overcome the fact that EU citizenship is a fundamentally strange creature. Whilst other courts are also criticised for a tendency to defer to international agreements and executive pressure, the EU features specific problems. ${ }^{83}$ It is fundamentally limited also by the leitmotifs of the Union. This became abundantly clear in the Melloni ${ }^{84}$ judgement, which raised significant concerns that the EU is unable to respond sensitively to the constitutional

${ }^{79}$ And this trend continues devaluing EU citizenship and disenchanting citizens. See Dimitry Kochenov, The Tjebbes Fail, European Papers, Vol. 4, 2019, No 1, European Forum, Insight of 25 April 2019, pp. 319-336.

${ }^{80}$ The serious crime restriction is watered down, as the decision as to what constitutes serious crime is left to the host state. See Mancano, supra note 68, pp. 62-65.

${ }^{81}$ False convictions do occur and indeed not all perpetrators of criminal acts are charged, let alone convicted.

82 This problem has also been amply demonstrated in case law with ship-source pollution (C-440/05, supra note 43), environmental crime (C-173/03, supra note 43) and C-43/12 European Commission v European Parliament and Council of the European Union [2014] EU:C-2014/298, which allowed the Commission to utilize a noncriminal justice basis for legislation with criminal justice impact. Criminal law has been relegated to its functional ability to give effect to EU policy. No special status is afforded to it (see also Mitsilegas, supra note 69, p. 22 et seq.) The same approach is to be found in the Kadi jurisprudence, supra note 60 , accepting counter-terrorism measures due to a link to the common market (see Mitsilegas, supra note 69, p. 25 et seq).

${ }^{83}$ See e.g. the Council of Europe context - J. Wadham, "Is the European Court of Human Rights buckling under Westminster pressure?" (3 February 2016) UK Human Rights Blog at https://ukhumanrightsblog.com/2016/02/03/is-the-europeancourt-of-human-rights-buckling-under-westminister-pressure/.

${ }^{84}$ C-399/11 Stefano Melloni v Ministerio Fiscal [2013] EU:C:2013:107. 
position of criminal justice measures and citizens affected by them. ${ }^{85}$ That case is widely seen as the CJEU asserting the primacy of EU law over national constitutional law when an area has been comprehensively regulated at the EU level. In this case, Spanish constitutional law's ability to require surrender to be conditional upon a retrial when an in absentia conviction has taken place was limited by the EAW legislation. Member states are thus not free to provide for higher constitutional protections where EU regulation has taken place and is deemed to be comprehensive. The major concern is that regulation at the EU level tends to orient towards the lowest common denominator of member states' protections, often at the lower end of what the European Convention foresees. ${ }^{86}$ In other words, Melloni legitimately gives rise to fears of policy-laundering for as long as executives dominate EU law. The failure to locate criminal justice matters at the heart of EU citizenship renders this sensitive policy area particularly vulnerable. It is unfeasible and, one might argue, unfair to expect the CJEU to correct a fundamental problem with citizenship as conceived at the EU level.

\subsection{The growing scope of work in service of EU citizens}

Whilst CJEU jurisprudence can certainly be seen as infused with expectations of citizenship on the part of Advocate Generals and judges (as well as citizens or the Commission prompting the underlying litigation), identifying EU work in the service of its citizens has become easier in recent years. Even within the jealously-guarded AFSJ, the EU citizen has become significant. The Framework Decision against Racism and Xenophobia ${ }^{87}$ is a notable example of legislation benefiting all EU citizens, as does victims' rights legisla-

\footnotetext{
${ }^{85}$ See Vanessa Franssen, "Melloni as a Wake-up Call - Setting Limits to Higher National Standards of Fundamental Rights' Protection" (10 March 2014) European Law Blog at https://europeanlawblog.eu/2014/03/10/melloni-as-a-wake-up-call-set ting-limits-to-higher-national-standards-of-fundamental-rights-protection/.

${ }^{86}$ Mitsilegas, supra note 69, p. 28.

${ }^{87}$ Council Framework Decision 2008/913/JHA of 28 November 2008 on combating certain forms and expressions of racism and xenophobia by means of criminal law OJ L 328. This legislation was also criticised as taking EU activity beyond the bounds of what is legitimate. See Jeni Iontcheva Turner, "The Expressive Dimension of EU Criminal Law" (2012) 60(2) The American Journal of Comparative Law, 555583.
} 
tion. ${ }^{88}$ The underlying idea that EU criminal justice mechanisms operate in service of the EU citizen has recently been directly stated by the legislation creating the EPPO. ${ }^{89}$ The 2018 suggestion to expand this office's powers to cover terrorism is also expressed as such. ${ }^{90}$ Though not well-conceived, and perhaps not always welcome, the EU citizen features in the minds of law-makers. For example, Article 86 TFEU speaks of EU action being allowed to combat serious crime where the cooperation of member states is necessary i.e. where doing so serves EU citizens better as a group.

These examples all seek to assist 'good' citizens: those worthy of protection in the minds of executive representatives legislating for them. However, citizenship rights are not just for the 'virtuous'. Furthermore, there is more to the EU than the Council alone. The increased role of the European Parliament in (even AFSJ) legislative procedures post-Lisbon is an expression of the elevated status of citizenship rights. ${ }^{91}$ This is the channel via which voting citizens can change their community. The Treaties feature the European citizen meaning both the Parliament and the Commission (as Guardian of the Treaties) must serve this figure. Recent years have seen a flurry of activity by the Parliament (and its LIBE $^{92}$ committee in particular) and the Commission in so-called 'rule of law' conflicts that serve EU citizens even when this means conflict with the elected governments of member states.

\footnotetext{
${ }^{88}$ Council Framework Decision 2001/220/JHA of 15 March 2001on the standing of victims in criminal proceedings OJ L 82. Note also C-105/03 Maria Pupino [2005] ECR I-05285, which ensured member states could not merely sign up to such legislation without implementing it. The CJEU famously endowed this legislative form with "indirect effect" and made sure EU citizens could rely upon EU legislation benefiting their rights, even if a member state dragged its feet. See Stefan Lorenzmeier, "Der Rahmenbeschluss als Handlungsform der Europäischen Union und seine Rechtswirkungen" (2006) 12 ZIS 576-582.

${ }^{89}$ See Council Regulation (EU) 2017/1939 of 12 October 2017 implementing enhanced cooperation on the establishment of the European Public Prosecutor's Office ("the EPPO") OJ L 283, Preamble 59 and 60. Note that this measure is one of enhanced cooperation, encompassing 22 member states. Its operational framework will be relevant to all who cooperate with it.

${ }^{90}$ European Commission Press Release, "State of the Union 2018: A reinforced European Public Prosecutor's Office to fight cross-border terrorism" (12 September 2018) https://ec.europa.eu/commission/presscorner/detail/en/IP_18_5682.

${ }^{91}$ See Maas, supra note 52.

${ }^{92}$ Committee on Civil Liberties, Justice and Home Affairs centrally concerned with citizenship rights qua its remit.
} 
Rule of law compliance activities are based upon article 7 TEU $^{93}$ empowering EU organs to protect the values enshrined in article 2 TEU. ${ }^{94}$ On a constitutional level, rule of law conflicts are an assertion that EU citizens are entitled to the rule of law, independent judiciaries, ${ }^{95}$ non-corrupt politicians and so forth. Unlike the highly technical debates the CJEU has often been drawn into, these require holistic understandings of citizenship, which also affects criminal justice mechanisms. They are also an expression of the understanding those populating EU organs have of citizenship and the values of the EU. This can be seen, for example, in the Injunction of 19th October 2018 issued by the Vice-President of the $\mathrm{CJEU}^{96}$ prompted by the European Commission, ordering the Polish Government to cease and desist in its reform of the judiciary for fear of irreparable damage to the rule of law until the case can be heard by the CJEU. Whilst it was mostly phrased in terms of EU interests, it also contained this statement:

the Vice-President recalls that the requirement of judicial independence forms part of the essence of the fundamental right to a fair trial, a right which is of cardinal importance as a guarantee that all the rights which individuals derive from EU law will be protected and that the values common to the Member States set out in Article 2 TEU, in particular the value of the rule of law, will be safeguarded. The infringement of a fundamental right such as the right to an independent court or tribunal is thus capable, because of the very nature of the infringed right, of giving rise in itself to serious and irreparable damage. ${ }^{97}$

93 This reads: "1. On a reasoned proposal by one third of the Member States, by the European Parliament or by the European Commission, the Council, acting by a majority of four fifths of its members after obtaining the consent of the European Parliament, may determine that there is a clear risk of a serious breach by a Member State of the values referred to in Article 2."

94 "The Union is founded on the values of respect for human dignity, freedom, democracy, equality, the rule of law and respect for human rights, including the rights of persons belonging to minorities. These values are common to the Member States in a society in which pluralism, non-discrimination, tolerance, justice, solidarity and equality between women and men prevail. '

${ }^{95}$ See the conflict with Poland, in particular Commission Recommendation 2018/ 103 of 20 December 2017regarding the rule of law in Poland complementary to Commission Recommendations (EU) 2016/1374 (EU) 2017/146 and (EU) 2017/ 1520; and the Commission's Letter of Formal Notice to Poland, European Commission Press Release, "Rule of Law: Commission Launches Infringement Procedure to Protect the Independence of the Polish Supreme Court" (2 July 2018) https://ec. europa.eu/commission/presscorner/detail/en/IP_18_4341.

${ }^{96}$ C-619/18 R European Commission v Republic of Poland [2018] EU:C:2018:1021.

97 Supra note, 92, p. 2. 
The damage referred to is feared for individual citizens relying on the judiciary to protect their rights against the Executive undertaking the reforms of the judiciary. The CJEU, as requested by the Commission, is thus lending concrete shape to the institutional provision the Treaties regard as necessary for all EU citizens. The on-going conflict with the Fidesz party in Hungary is, perhaps, more strongly marked as an immigration conflict. Nevertheless, the Parliament report of 12th July 2018 (which called upon the Council to pursue Hungary under Art 7 for 'serious breaches' of the values on with the EU is founded) declared,

whereas any clear risk of a serious breach by a Member State of the values enshrined in Article 2 TEU does not concern solely the individual Member State where the risk materialises but has an impact on the other Member States, on mutual trust between them and on the very nature of the Union and its citizens' fundamental rights under Union law. ${ }^{98}$

The individual rights protection of all citizens is therewith declared a fundamental concern of EU organs.

Such concern is apparent also in recent Parliamentary activities relating to both Malta and the Slovak Republic. These appear to indicate that EU citizens are entitled to certain protections and that the Union's organs will step in where national structures fail. Thus, in Malta the assassination of an investigative journalist in October 2017 led to a Parliamentary Resolution calling for an independent international investigation. ${ }^{99}$ It noted serious concerns regarding the rule of law, democracy and fundamental rights. Continued monitoring mechanisms ${ }^{100}$ and findings of inadequacy clearly represent intervention on citizens' behalf. Similarly, when European Parliamentarians called for Europol agents to investigate the organised crime-

\footnotetext{
${ }^{98}$ Motion for a European Parliament Resolution on a Proposal calling on the Council to determine, pursuant to article 7(1) of the Treaty of the European Union, the existence of a clear risk of a serious breach by Hungary of the values upon which the Union is founded, 2017/2131(INL) Preamble B. http://www.europarl.europa.eu/ doceo/document/A-8-2018-0250_EN.html.

${ }^{99}$ European Parliament Resolution 2017/2935(RSP) of 15 November 2017 on the rule of law in Malta.

${ }^{100}$ A LIBE Committee mission reported on in January 2018 and pressure exerted upon the Maltese government (e.g. in September 2018) see European Parliament, "Mission Report: Following the Ad-hoc Delegation to Slovakia and Malta 17-20 September 2018" (16 November 2018) Committee on Civil Liberties, Justice and Home Affairs https://www.europarl.europa.eu/meetdocs/2014_2019/plmrep/COM MITTEES/LIBE/DV/2018/11-19/1169408EN.pdf.
} 
related murder of two journalists in the Slovak Republic, this added to the pressure on the Prime Minister to step down. ${ }^{101}$ A LIBE delegation visit in April 2018 led to an EU Parliament Resolution for the protection of journalists in Europe. ${ }^{102}$ A joint investigation team was also established by Europol and the agency reported in October 2018 that Slovak Police carried out arrests in connection with the murders. ${ }^{103}$ In June 2018 the LIBE Committee furthermore established a Rule of Law Monitoring Group (ROLMG). ${ }^{104}$ EU Parliamentarians are thus clearly taking up the defence of citizens' rights and interests where they recognise more local structures as failing to do so.

Whilst such undertakings are activities serving EU citizens in their infancy, they are notable in terms of EU organs embracing their responsibilities to EU citizens, who are entitled to certain protections. These institutions bring pressure to bear upon democratically elected governments in order to protect EU citizenship and those that hold it. Readers sceptical of the impact such action can have may note the parallels with the huge push at the Federal level in the US, which is suggested to be the result of federal law enforcement structures protecting the civil rights of African-Americans to ensure they were afforded the protection of criminal law in the 1960s. ${ }^{105}$

Centrally, parliamentary and commission workers and other holders of EU positions have their own ideas of citizenship. When EU legislation speaks of citizens, this resonates with whatever understanding officials charged with implementation have of such terms. The vocabulary of values and citizenship is weighty. At the European level, understanding of these concepts seems sufficiently uniform and clear for EU officials to act in reaction to, or in harmony with, these ideas, and thus it matters little whether the Council was

${ }^{101}$ See Jennifer Rankin, "Bring in EU Police over journalist's murder, MEPs urge Slovakia" (13 March 2018) The Guardian, https://www.theguardian.com/world/ 2018/mar/13/slovakia-should-hand-over-journalist-murder-inquiry-say-meps.

102 European Parliament Resolution 2018/2628(RSP) of 19 April 2018 on protection of investigative journalists in Europe: the case of Slovak journalists Ján Kuciak and Martina Kušnírová.

${ }^{103}$ Europol, "Arrests in Slovakia” (2 October 2018) Press Release, https://www. europol.europa.eu/newsroom/news/arrests-in-slovakia.

${ }^{104}$ See European Parliament resolution 2018/2965(RSP) of 28 March 2019 on the situation of the rule of law and the fight against corruption in the EU, specifically in Malta and Slovakia, Preamble A.

${ }^{105}$ See US Department of Justice, "Civil Rights Division Accomplishments 20092012” https://www.justice.gov/crt/us-department-justice-civil-rights-division-accom plishmnts-2009-2012. 
thinking only of economics when formulating such legislation. What they poured into law were notions of citizenship and values. These words consequently have legal meaning for both citizens and the practice of the AFSJ.

Under extreme circumstances, such notions of EU citizens demarcate CJEU jurisprudence. The famous Kadi case saw the Court dig deep to articulate thinking of this sort relating to values. It declared that,

Fundamental rights form an integral part of the general principles of law whose observance the Court ensures. For that purpose, the Court draws inspiration from the constitutional traditions common to the Member States and from the guidelines supplied by international instruments for the protection of human rights on which the Member States have collaborated or to which they are signatories. In that regard, the European Convention for the Protection of Human Rights and Fundamental Freedoms has special significance. Respect for human rights is therefore a condition of the lawfulness of Community acts, and measures incompatible with respect for human rights are not acceptable in the Community. ${ }^{106}$ The cultural and legal framework of the member states and European concepts such as citizenship thus have a role to play in informing the interpretation of EU law and action. This is because the Court and other relevant actors recognise the legitimacy of expectations that all EU action is informed by and in accordance with common values. The problem remains, however, that until this form of citizenship is endowed with a proper legal definition and language, it is vulnerable. The activities that the European Commission is tasked with as guardian of Article 7 TEU and the manner in which it places EU actors in direct conflict with member states governments lends further urgency to calls for EU citizenship to be made truly worthy of the name. The battle of values is key also to ensuring the continued survival of the functional balance of tasks between EU and member states as they currently operate. ${ }^{107}$

${ }^{106}$ US Department of Justice, supra note 101, para 5.

107 This battle is far from merely theoretical in relation to rights protection, for example. Within the network between EU and national courts there is a delicate balance expressed by the German Bundesverfassungsgericht in the solange judgement (Internationale Handelsgesellschaft mbH v Einfuhr- und Vorratsstelle für Getriede und Futtermittel [1970] 11/70 ("Solange I"); Re Wünsche Handelsgessellschaft [1986] EVerfGE 73, 339 ("Solange II")). How the German Court would view the equivalency of EU rights protection as assumable in the face of confirmed Article 7 breaches is a much more difficult and explosive question. 


\subsection{The EU and criminal justice}

The fundamental problem from a criminal justice perspective is that citizenship within the EU opens one up to super-charged repressive measures without the protections national criminal justice mechanisms contain. From a citizenship perspective, the key function of effective constraint of state power is not being fulfilled. European citizens benefit from repressive EU criminal justice measures, however, in that citizens who can become victims of crime are doubtlessly served by functional criminal justice systems with the capacities that enable law enforcement to match the freedom of movement provided to people, goods, capital and services by EU governance. Member state governments (and the EU) doubtlessly serve citizens via the mechanisms and institutions found at the EU level. The Schengen rules, ${ }^{108}$ for example, certainly make sense in ensuring freedom of movement is matched by law enforcement capacities. As in other areas, the innovations offered by the EU in the criminal justice arena enhance the lives of citizens.

Criminal justice mechanisms at the EU level overwhelmingly increase and enhance executive action. ${ }^{109}$ The centre-piece (the EAW $)^{110}$ is now flanked by the European Investigation Order $(E I O)^{111}$ and specific legislation approximating definitions of crime, making cross-border investigations simpler. ${ }^{112}$ Importantly, however,

${ }^{108}$ See Thomas Wahl and Sarah Schultz, "The Enlargement of the Schengen Area" (2007) 3-4/2007 Eucrim 66-67; Ministry of the Interior of the Slovak Republic, "Schengen Police Cooperation" at https://www.minv.sk/?Schenegn_po lice_cooperation.

${ }^{109}$ See e.g. Lorena Bachmeier, "Fundamental Rights and Effectiveness in the European AFSJ: The Continuous and Never Easy Challenge of Striking the Right Balance" (2018) 1 Eucrim 56-63.

${ }^{110}$ A first, revolutionary move trumping national constitutional protections such as the double criminality requirement and particularly extradition prohibitions to ensure offenders taking advantage of freedom of movement rights could not avoid efficacious arrest warrants. See Joanna Dawson, Sally Lipscombe and Samantha Godec, "The European Arrest Warrant" (2017) House of Commons Library, Briefing Paper 07016; Massimo Fichera, "The European Arrest Warrant and the Sovereign State: A Marriage of Convenience?" (2009) 15(1) European Law Journal 70-97.

${ }^{111}$ Inés Armada, "The European Investigation Order and the Lack of European Standards for Gathering Evidence: Is a Fundamental Rights-Based Refusal the Solution?" (2015) 6(1) New J. of EU Criminal Law 8-31.

${ }^{112}$ For example, Directive 2011/36/EU of 5 April 2011 on combating and preventing trafficking in human beings and protecting its victims, and replacing Council Framework Decision 2002/629/JHA OJ L 101/1; and, Directive (EU) 2017/541 of the 
the criminal justice advances at the EU level relate not only to legal mechanisms but also to powerful institutional developments. ${ }^{113}$ Support is provided to investigators via Europol ${ }^{114}$ and Eurojust ${ }^{115}$ as demonstrated by, for example, Theresa May (mid-Brexit negotiations) standing before the press the day after the 2017 Manchester bombing and repeating the views of the Europol Director as to the UK's threat position. ${ }^{116}$ These institutions provide cooperation hubs, operate as powerful intelligence centres (particularly in the case of Eurojust) in which requested measures can be chased up and joint decisions made. All this takes place without specific or specialised legal oversight being foreseen ${ }^{117}$ and with limited accountability capacity. ${ }^{118}$

The analysis and intelligence capacities provided institutionally are matched by databases accessible to law enforcement agents across the Union. The European Criminal Record Information System (ECRIS) is a key recent innovation, but systems like Pruem, Schen-

\section{Footnote 112 continued}

European Parliament and of the Council of 15 March 2017 on combating terrorism and replacing Council Framework Decision 2002/475/JHA and amending Council Decision 2005/671/JHA OJ L 88.

${ }^{113}$ See Kai Ambos, European Criminal Law (Cambridge University Press, 2018) p. $560-616$.

${ }^{114}$ See Alexandra De Moor and Gert Vermeulen, "The Europol Council Decision: Transforming Europol into an Agency of the European Union" (2010) 47 Common Market Law Review 1089-1121

${ }^{115}$ Michiel Luchtman and John Vervaele, "European Agencies for Criminal Justice and Shared Enforcement (Eurojust and the European Public Prosecutor's Office)" (2014) 10 Utrecht L. Rev. 132-150.

${ }^{116}$ BBC News, "Manchester attack: Theresa May Terror Threat Speech in Full" (23 May 2017) athttps://www.bbc.co.uk/news/uk-40023457.

${ }^{117}$ Because decisions are treated as matters internal to these institutions and remain opaque for the defence (so even e.g. Article 41 of the Charter cannot be triggered). See Luchtman and Vervaele, supra note 110, 138.

118 Compare Europol's governing structure to that of national police bodies/intelligence services. See Sonja Puntscher Riekmann, "Security, Freedom and Accountability: Europol and Frontex", in Elspeth Guild and Florian Geyer (eds.), Security versus Justice? (Routledge: Taylor and Francis, 2008). Note also that the much vaunted difference between Europol and national police services - namely the fact that Europol possesses no operational powers - fails to acknowledge what proportion of police work consists of data analysis for serious crime, as opposed to the utilisation of operational powers. See Marianne L. Wade, "General Principles of Transnationalised Criminal Justice?” (2013) 9(4) Utrecht Law Review 165-83. 
gen II, and Eurodac are also immensely valuable. ${ }^{119}$ Harder to determine in character are provisions made within the Council such as the Joint Intelligence Centre, ${ }^{120}$ the Counter-terrorism Coordinator $^{121}$ and the Anti-Trafficking Coordinator. ${ }^{122}$ Mechanisms such as Joint Investigation Teams (JITs) ${ }^{123}$ are legally complex to define as European since they are run in accordance with the law of the member state agreed by the cooperating agencies. A contractual template, set-up support and funding are, however, available from Europol and Eurojust, surely rendering the legal designation as purely national infrastructure misleading. ${ }^{124}$ Agents of both those agencies can be seconded, thus becoming operational criminal justice practitioners.

At the time of writing, the next revolutionary step is being undertaken in the shape of appointment proceedings for the EPPO. ${ }^{125}$ This genuinely supra-national criminal justice agency is being created to protect the financial interests of the $\mathrm{EU}^{126}$ but also has powers to 'investigate, prosecute and bring to justice' ancillary offences. ${ }^{127}$ As noted above, the model function of this agency can

${ }^{119}$ For an introduction, see André Klip, European Criminal Law: An Integrative Approach (Intersentia, 2016) p. 482 et seq.

${ }^{120}$ Now known as the EU Intelligence Analysis Centre, previously SitCen. See EEAS Fact Sheet, "EUINTCEN Intelligence Analysis Centre" (05 February 2015) at http://statewatch.org/news/2016/may/eu-intcen-factsheet.pdf.

${ }^{121}$ European Council, "Counter-Terrorism Coordinator" at https://www.con silium.europa.eu/en/policies/fight-against-terrorism/counter-terrorism-coordinator/

${ }^{122}$ European Commission, "EU Anti-Trafficking Coordinator" at https://ec. europa.eu/anti-trafficking/eu-anti-trafficking-coordinator_en.

${ }^{123}$ Europol, "Joint Investigation Teams - JITS" at https://www.europol.europa. eu/activities-services/joint-investigation-teams.

${ }^{124}$ See Tom Schalken and Maarten Pronk, "On Joint Investigation Teams, Europol and Supervision of Their Joint Actions" in Hans-Jörg Albrecht and André Klip (eds.) Crime, Criminal Law and Criminal Justice in Europe (Brill, 2013) pp. 423437; and M. Plachta, "Joint Investigation Teams" 13 European Journal of Crime, Criminal Law and Criminal Justice 284-302; Bart de Buck, "Joint Investigation Teams: The Participation of Europol Officials" (2007) 8(2) ERA Forum 253-264.

${ }^{125}$ For updates see European Commission, "European Public Prosecutor's Office" at https://ec.europa.eu/info/law/cross-border-cases/judicial-cooperation/net works-and-bodies-supporting-judicial-cooperation/european-public-prosecutors-of fice_en\#mission.

${ }^{126}$ Defined in accordance with Directive (EU) 2017/1371 of the European Parliament and of the Council of 5 July 2017 on the fight against fraud to the Union's financial interests by means of criminal law, OJ L 198.

${ }^{127}$ Article 22(3) of Regulation 2017/1939, supra note 85; see also Preamble 56. 
already be traced with an expansion of EPPO powers to terrorism proposed in 2018. ${ }^{128}$

From a criminal justice perspective, it is impossible to formally distinguish the EU citizen from the member state citizen. The member states clearly did not set out with the EU citizen in mind when invoking criminal justice mechanisms at the EU level. The adoption of early criminal justice measures via the Third Pillar of the EU (deliberately segregated to remain inter-governmental in nature) intended these mechanisms to enhance the cooperation of national criminal justice systems only. This was EU law as a mutation of mutual legal cooperation: improved, but not fundamentally different. The density and importance of what these mechanisms have become, however, now justifies discussion of them as a system of sorts and thus also of the EU as a level of criminal justice governance. Cor-

${ }^{128}$ Few policy areas have impacted more strongly upon citizenship matters than counter-terrorism with national governments driving to undermine the absolute nature of the ban on torture. See Christopher Michaelsen, "The Renaissance of NonRefoulement? The Othman (Abu Qatada) Decision of the European Court of Human Rights" (2012) 61(3) ICLJ 750-65), schemes depriving citizens of their status (see e.g. the Begum and Letts cases e.g. Steve Hewitt, "Why the UK Could Regret Angering Canada by Stripping IS Suspect Jack Letts of British Citizenship" (20 August 2019) The Conversation at http://theconversation.com/why-the-uk-could-re gret-angering-canada-by-stripping-is-suspect-jack-letts-of-british-citizenship-122081 ), exceptional measures like control orders (see Adrian Hunt, "From Control Orders to TPIMs: Variations on a Number of Themes in British Legal Responses to Ter rorism Crime" (2012) 62(3) Crime, Law and Social Change 289-321), EU necessitated constitutional change (see Damjan Korosec, "Anti-Terrorism Related Law Reforms and Human Rights in Slovenia", in Marianne L. Wade and Amir Maljević (eds.), $A$ War on Terror? The European Stance on a New Threat, Changing Laws and Human Rights Implications (Springer 2009) pp. 245-259; Davor Derenčinović, "The Evolu tion of the Antiterror Legal and Institutional Framework in Croatia", in Marianne L. Wade and Amir Maljević (eds.) A War on Terror? The European Stance on a New Threat, Changing Laws and Human Rights Implications (Springer 2009) pp. 305-320 and for broader analysis, see Cian C. Murphy Transnational counter-terrorism law: law, power and legitimacy in the "wars on terror", Transnational Legal The ory (2015), 6:1, pp. 31-54. The tabling of a truly supra-national criminal justice agency in the current policy-laundering space is cause for alarm bells to shrill; all the more so when one considers the structural deficits of the EPPO as established. There is simply no structure foreseen for the policy direction one would expect for a prosecution service nor effective political, let alone legal accountability (on this see, Tommaso Rafaraci, "Brief Notes on the European Public Prosecutors Office" pp. 157-163, Marianne L. Wade, "The European Public Prosecutor: Controversy Ex pressed in Structural Form," pp. 165-180 and Martin Böse, "Judicial Control of the European Public Prosecutor's Office," pp. 191-202, all in Tommasso Rafaraci and Rosanna Belfiore (eds.), EU Criminal Justice (Springer, 2019). 
responding holistic consideration of citizenship matters in relation to that governance level then becomes an obvious, and gaping, lacuna.

\subsubsection{EU criminal justice and the CJEU}

The lack of consideration afforded to citizenship rights in EU criminal justice matters has led to specific challenges before the CJEU. In direct encounters with this policy area, the Court has a mixed track record, viewing criminal justice mechanisms in their constitutional setting. Unsurprisingly, it proved impossible to keep these entirely out of the remit of EU court oversight despite the member states' (pre-Lisbon) intentions. The AFSJ is marked by challenging ideas requiring interpretation, not least the presumption of mutual trust among member states' systems. ${ }^{129}$ As one would expect, given the setup described above, AFSJ matters did not come before the CJEU specifically badged as citizenship matters. Nevertheless, as should have become clear, criminal justice matters clearly have ramifications for citizenship.

On the one hand, the CJEU (in Aranyosi and Căldăraru, for example $)^{130}$ recently provided a clear basis for constitutional arguments to override the mutual trust just described. This is a rejection of the top-down perspective on rights matters and an insistence that the circumstances of each individual citizen must be evaluated when they are subject to criminal justice mechanisms. The Court recognised the EAW's fundamental rights impact, referring specifically to basics of EU constitutionality (article 4 of the Charter, referring to art 3 ECHR). ${ }^{131}$ On the other hand, the CJEU has not proved immune to the pressures of politically sensitive issues, such as immigration and the treatment of criminals. The Wolzenburg case saw the CJEU accepting member states' assertions that it takes a considerable amount of time for a citizen to form attachments to a country of residence, which has relevance to criminal justice decision-making. Accordingly, until a citizen has resided uninterrupted in a nation for five years, the connection to the state of origin was considered weak and could be over-ridden. ${ }^{132}$ Given how well-established family life could become in a far shorter time, this means a long wait before the citizen can see her choices turned into meaningful citizenship pro-

${ }^{129}$ For an overview of the relevant law see Klip, supra note 114 , 100 et seq.

${ }^{130}$ Joined Cases C-404/15 and C-659/15 PPU Pál Aranyosi and Robert Cāldāraru v Generalstaatsanwaltschaft Bremen [2016] EU:C:2016:198.

${ }^{131}$ C-404/15, supra note 125.

132 C-123/08, supra note 42. 
tections. The more individualized approach taken previously in Kozlowski ${ }^{133}$ appeared more compatible with a notion of meaningful EU citizenship. Wolzenburg seems to embrace a reasserted dominance of national considerations and the idea of national identity. The Da Silva Jorge ${ }^{134}$ case may be viewed as the CJEU attempting to correct this somewhat, insisting upon a uniform European definition of exceptions to EAW refusals, not those restricted to own nationals only, but the sense of the Court being overwhelmed by political reality (and therewith the legal strength of citizens subject to executive pressure) remains.

The CJEU has demonstrated considerable capacity to protect fundamental rights and thus ensure citizenship values are operationalized at the EU level. However, the Court has not integrated such adjudications into its EU citizenship arguments. The more recent submission to pressure is also reflected in the $\mathrm{LM}^{135}$ case, which demonstrates the tightrope the Court is still walking in relation to the AFSJ. The Court acknowledged ${ }^{136}$ that a reasoned Commission finding of an article 7(1) breach, combined with factors from a suspect's personal situation, the nature of the offence and the factual context underlying an EAW, may provide sufficient evidence to demonstrate a risk of fundamental rights breaches to that citizen.

However, the Court's deference to the traditional structures of the EU shone through, emphasising relevant determinations as fundamentally a matter of judgment for the Council. Any suspension of the EAW results from 'serious and persistent' breaches of article 2. Only where the Council has made such a determination must member state authorities refuse EAWs from an affected member state. ${ }^{137}$ It went on to set out that anything short of a Council determination leaves the citizen dependent upon the judicial authorities in the surrendering state determining a specific, individual risk of a fundamental rights breach. ${ }^{138}$ In other words, citizenship considerations remain at the mercy of an executive organ. If it fails to act, individuals are dependent upon a local court being willing to find a member state of the Union set to breach fundamental rights (ignoring all political

\footnotetext{
133 C-66/08, supra note 42.

134 C-42/11 João Pedro Lopes Da Silva Jorge [2012] EU:C:2012:517.

${ }^{135}$ C-216/18 PPU LM [2018] EU:C:2018:586.

136 Supra note 130, para. 79.

${ }^{137}$ Supra note 130, paras. 70-72.

138 Supra note, 130, para. 73.
} 
ramifications) in order to afford an individual citizen effective protection. As we have seen, this is a step the CJEU itself has hesitated to take.

This interplay with Council decisions furthermore demonstrates the importance of the rule of law proceedings described above. The concern over backtracking as regards judicial independence in Romania, ${ }^{139}$ whilst not phrased in the language of citizenship rights, triggered EU organs to take steps to protect themselves (via the suspension of access to funding), which has ramifications for the EAW following this reasoning. Transferred into the AFSJ such activity should provide the CJEU with the kind of evidence relevant in the Aranyosi and Căldăraru ${ }^{140}$ sense: concrete evidence rebutting the presumption of mutual trust and thus forming grounds for a refusal to implement a EAW, for example), and reiterated in LM, when conflicts with citizens arise. The reference to mutual trust in the rule of law conflict with Hungary described above also becomes an important flashpoint, as all mutual recognition instruments are based upon this. Such a flaw should trigger citizenship protections via Aranyosi and Căldăraru. The question is what happens to rule of law conflicts when the impact of any official finding upon the operation of the AFSJ becomes recognised. Will the CJEU and other Courts follow through, protecting individual rights even at such a high cost?

To be clear, every EU citizen faces a scenario in which the executive of her state of residence has opened her up to the assumption (by any judicial organ to which she might appeal) that the assertions of another executive should be assumed correct, with minimal information provided, trusting in both the system of the requesting state and the good faith of the individual measure (usually an EAW). LM confirms that, failing a situation in which the majority of the 28

${ }^{139}$ See European Commission Press Release, "Joint Statement of the European Commission President Juncker and First Vice-President Timmermans on the Latest Developments in Romania" (January 2018) at https:/ec.europa.eu/commission/ presscorner/detail/en/STATEMENT_18_423; and the Annual Cooperation and Verification Mechanism (CMV) Report of November 2018, see European Commis sion Press Release, "European Commission's Progress Report on Romania under the Cooperation and Verification Mechanism" (November 2018) at https://ec.euro pa.eu/commission/presscorner/detail/en/IP_18_6365, stating that this will not end until the rule of law demands of the January 2017 report have been fulfilled.

${ }^{140}$ The Court emphasises "implementation of the mechanism of the European arrest warrant as such may be suspended only in the event of serious and persistent breach by one of the Member States of the principles referred to in Article 2 TEU, and in accordance with the procedure provided for in Article 7 TEU" (para 81). 
executives have formally agreed that one of their number is in breach of fundamental values, the burden of proof remains upon an individual citizen to prove that the executive of a country in which she likely does not reside may endanger her fundamental rights. It is difficult to overstate how far removed this model is from placing citizenship at the heart of governance. The reliance upon Council findings related to LM sets a high bar. If EU parliamentary bodies, the Commission or even the CJEU (in infringement proceedings, for instance) reach an official finding of article 7 breaches, will a citizen's legitimate expectation that these influence decision-making in criminal processes be ignored if the Council could have acted, but has not? Can any governance level purporting to act in the interest of its citizens make a plausible claim for legitimacy in such circumstances?

Fundamental rights protection is clearly an important part of any citizenship package. Different strands of CJEU jurisprudence can be traced without necessarily forming a harmonious whole, however, and criminal justice matters are particularly dislocated. Thus the Advocate-General's Opinion in LM strongly invoked the earlier case of Radu ${ }^{141}$ in harmony with broader decisions of the Court such as NS and Others ${ }^{142}$ and CK and others v Republika Slovenia, ${ }^{143}$ which underlined that the fundamental rights of asylum seekers must be respected in member state decision-making. In these cases, article 4 of the Charter and the holistic nature of the protection from torture and inhumane treatment were taken as fundamental and thus shut down technical arguments as to what has to be considered. ${ }^{144}$ Effective, constitutional protection in line with more conventional notions of citizenship was clearly the Court's guiding principle here, but its concern was not explicitly the protection of EU constitutionality or EU citizenship rights. Further, the Court's refusal to transfer this strand of jurisprudence to the AFSJ in LM highlights the vulnerability of that policy area as currently conceived.

More conventional models of citizenship according more closely with citizens' expectations would draw more clearly upon the idea of a relationship between governance level and citizen. CJEU jurispru-

\footnotetext{
${ }^{141}$ C-396/11 Ciprian Vasile Radu [2013] EU:C:2013:39.

142 Joined Cases C-411/10 and C-493/10 N.S. (C-411/10) v Secretary of State for the Home Department and M.E. and Others (C-493/10) v Refugee Applications Commissioner and Minister for Justice, Equality and Law Reform [2011] ECR I13905.

143 C-578/16 PPU C.K. and Others v Republika Slovenija [2017] EU:C:2017:127.

${ }^{144}$ Mitsilegas, supra note 69, p. 233.
} 
dence is often marked by the relationship between suspect and the relevant member state in criminal justice matters, with any EU role obscured. ${ }^{145}$ The criminal justice perspective, however, demands honest recognition of the role the EU plays in citizens' lives and criminal matters, and a corresponding arrangement of citizenship rights. It is simply too much to demand of local courts (and the criminal justice practitioners serving them) that they furnish even the informational demands LM places upon them. Again, this is a scenario which a top-down perspective on citizenship rights might deem acceptable. However, from the perspective of an individual citizen with her legitimate expectation of a criminal process, this is far from the case. This is arguably a scenario in which citizenship is distinctly not felt in the local and thus is the very opposite of what Tonkiss identifies as ensuring citizenship is meaningful.

It would be unfair not to recognise the top-down versus individual citizenship dichotomy presented here as a useful tool but not truly reflective of EU activity as a whole. In many ways the history of the AFSJ can be understood as an on-going battle between those member states (and thus segments of the Council) willing to utilise criminal justice mechanisms in service of all EU citizens (i.e. including those accused of criminal behaviour) and those who oppose this. ${ }^{146}$ Considerable efforts have been undertaken at the EU level in relation to criminal justice with a more holistic view of citizenship in mind. Whilst the broader attempt to legislate for defence rights must be considered defeated, it involved a Framework Decision ${ }^{147}$ tabled and pushed by the Commission as well as another attempt by the German

${ }^{145}$ As we have seen, however, this can also occur within more central EU policy areas relating to asylum and indeed freedom of movement of persons.

${ }^{146}$ See Maas, supra note 52, p. 412 et seq. The Irish Government when presenting it and the UK's opposition to the Framework Decision on Fundamental Rights in Criminal Proceedings spoke of this legislation as "precisely the kind of thing the EU should not be doing" at a German Presidency conference in 2006. The UK government's Brexit Security White Paper very clearly demonstrates a position that ignores the need for anything but repressive powers and enhancement - see HM Government, Security, Law Enforcement and Criminal Justice: A Future Partnership Paper, 18 September 2017 available at: https://www.gov.uk/government/up loads/system/uploads/attachment_data/file/645416/Security_law_enforcement_ and_criminal_justice_-_a_future_partnership_paper.PDF.

${ }^{147}$ Proposal for a council framework Decision on certain procedural rights in criminal proceedings throughout the European Union $\{\mathrm{SEC}(2004) 491\} / * \mathrm{COM} /$ 2004/0328 final at https://eur-lex.europa.eu/legal-content/EN/TXT/?uri $=$ CELEX\% 3A52004PC0328. 
Presidency in $2006 .{ }^{148}$ This also failed, but not for lack of effort. Furthermore, the Swedish Presidency revisited the topic in 2009 and the resulting Stockholm Programme provided for detailed regulation of a few individual procedural rights. ${ }^{149}$ Clearly, also within the Council, varied expectations of what citizenship requires and means for correct governance are in play. They are, however, not a matter on which political consensus is achievable. Attempts at this have now been abandoned. In its latest AFSJ policy declarations the Council speaks only of consolidation and the implementation of previously introduced measures. ${ }^{150}$ Presumably this is a declaration to block defence rights measures because it has not diminished the capacity of 22 member states to bring the EPPO into being. ${ }^{151}$ The creation of an equivalent institution was never foreseen for defence lawyers and even the creation of support mechanisms for procedural rights appears blocked for the foreseeable future. ${ }^{152}$

While one cannot justly declare the EU legislature as entirely neglecting the broader citizenship dimensions of criminal justice, it does seem to lack motivation in this regard. The EAW was undeniably well-established before the Stockholm Programme was even conceived. The investigation order was passed as an approved mechanism even before the Evidence Warrant legislation was set to be implemented. ${ }^{153}$ In comparison, there is simply no denying the lagging timeline of legislative provision for other measures one might qualify as liberty-protecting, ${ }^{154}$ nor their slow implementation in

${ }^{148}$ Marianne Wade, "Deep Rifts on Procedural Guarantees Mirrored at Conference in Berlin" (2007) 1-2 Eucrim 31.

${ }^{149}$ Cornelia Riehle and Allison Clozel, "10 Years After the Roadmap: Procedural Rights in Criminal Proceedings in the EU Today" (2019)ERA Forum, https://doi. org/10.1007/s12027-019-00579-5.

${ }^{150}$ European Council Conclusions 26-27th June 2014, Brussels, EUCO 79/14, para 3.

${ }^{151}$ Council Regulation (EU) 2017/1939 of 12 October 2017 implementing enhanced cooperation on the establishment of the European Public Prosecutor's Office ("the EPPO') OJ L 283.

${ }^{152}$ See the resistance to the budgetary implications of measure $\mathrm{C}$ of the Stockholm Programme for instance. Sarah Ludford, The European Arrest Warrant: issues and solutions (October 2013) Speech given at the ALDE group, European Parliament, Brussels.

${ }^{153}$ Martyna Kusak, "Mutual Admissibility of Evidence and the European Investigation Order: Aspirations Lost in Reality" (2019) 19(3) ERA Forum 391-400. https://doi.org/10.1007/s12027-018-0537-0.

${ }^{154}$ See Klip, supra note 114 , p. 438 et seq. 
terms of national law and practice. ${ }^{155}$ Even when passed, individual measures that might hugely benefit suspects such as Eurobail ${ }^{156}$ become greatly delayed and remain largely unused. ${ }^{157}$ Measures such as the Framework Decision on the Transfer of Prisoners, ${ }^{158}$ which might be viewed as a mechanism to ensure successful rehabilitation ${ }^{159}$ (by supporting family visiting rights, for example), reveal their true character via the declaration that the consent of the person affected is not necessary. ${ }^{160}$ In other words, the member states envisage this as a tool for themselves, not incarcerated citizens. Practice has furthermore demonstrated that citizens remain very much at the mercy of the member states as to whether it will be utilised to ensure prisoners are returned to the member state of their choice (to be closer to their family, for example). ${ }^{161}$

It is important to stress that this is not the result of decisions being made at the EU level. This is very much the status quo being created and vigorously defended by member states as part of that collective. Frequently, of course, such decisions are made within the Council. Nevertheless, arguments advanced are distinctly national in nature and backed by arguments pertaining to the principle of subsidiarity

${ }^{155}$ See e.g. Riehle and Cloyel, supra note 144, 3.

${ }^{156}$ Council Framework Decision 2009/829/JHA of 23 October 2009 on the application, between Member States of the EU, of the principle of mutual recognition to decisions on supervision measures as an alternative to provisional detention, OJ L 294/20.

${ }^{157}$ See COM (2014) 57 Final: Report from the Commission to the European Parliament and Council on the implementation by the Member States of the Framework Decisions 2008/909/JHA, 2008/947/JHA and 2009/829/JHA on the mutual recognition of judicial decisions on custodial sentences or measures involving deprivation of liberty, on probation decisions and alternative sanctions and on supervision measures as an alternative to provisional detention.

158 Council Framework Decision 2008/909/JHA of 27 November 2008 on the application of the principle of mutual recognition to judgments in criminal matters imposing custodial sentences or measures involving deprivation of liberty for the purpose of their enforcement in the European Union OJ L 327, pp. 27-46.

${ }^{159}$ Reiterated as the core aim of criminal sanctions under EU law, reconfirmed by A.G. Bot in C-145/09 Tsakouridis, supra note 28, AG Opinion delivered 8th June 2010.

${ }^{160}$ Preamble recital 5 FD 2008/909/JHA of 27th of November 2008, supra note 153. For extensive analysis see Mitsilegas, supra note 69.

${ }^{161}$ See, for example, the refusal of the Netherlands to repatriate its own nationals because of the large number convicted for drug smuggling offences. The financial considerations of the Dutch prison service are regarded as more important than the effective rehabilitation of prisoners. 
and the overriding need to respect the sovereignty of nation states. The superiority of states - represented as they are by their executives - comes at the expense of the individual rights of citizens and the power of other arms of government (legislature and judiciary). The Council apparently does not appreciate that member states acting collectively as the Council constitute a distinctly different level of governance and as such owes distinctive duties and protections to its citizens collectively (as opposed to a collection of member state citizens).

Whilst arrangements preceding the Treaty of Lisbon perhaps lent legitimacy to an argument that the EU was simply a forum of mutated transnational criminal law - an area of intense mutual legal cooperation - the integration of the AFSJ into EU law proper (since the Treaty came into force) renders that point moot. The EU now undeniably has significant legislative power in criminal justice matters. Institutions such as Europol and Eurojust have become agencies of the Union, funded from its budget. Further, development intensifying the investigative, informational and institutional power of criminal justice mechanisms at the EU level continues unabated. It is, therefore, undeniably time for an honest re-evaluation of the relationship between EU citizens and this governance level as a criminal justice actor. ${ }^{162}$

\section{THE EUROPEAN UNION CITIZEN: SERVED AND IGNORED BY THE AFSJ}

The EU is an executive-dominated governance level at which measures are being passed and implemented that massively benefit executive organs in the exercise of their powers. Even where concern is raised as to the balance of criminal justice, legislation passed to support defence rights is far less effective and far from comprehensive in nature. As the Council becomes less dominant in legislative pro-

\footnotetext{
${ }^{162}$ The practical consequences need not be as dramatic as one might imagine. For example, citizenship rights would already be considerably advanced by an individual being empowered to insist upon executive agencies within her member state of residence implementing and stringently applying liberty-enhancing measures as efficiently as it does repressive EU measures. If Eurobail was applied, for example, a European citizen could insist on the mutual recognition of bail orders so that they remain at liberty (adhering to reasonable reporting restrictions), within their normal setting, up to the trial date set by the relevant jurisdiction, rather than the EAW and surrender pending trial being the "go-to" option as is currently the case. Indeed, from a fiscal and fundamental rights perspective, this would be desirable.
} 
ceedings post-Lisbon, this situation may change, but it is important to note that the Council still requires use of the extraordinary legislative procedure (in which it remains dominant) for the most sensitive provisions in this area. Furthermore, it inserted so-called 'emergency break' provisions to ensure member states cannot be overrun in this policy area. ${ }^{163}$ As matters stand, the EU clearly affords member states mechanisms by which the arm of law enforcement can be boosted in a transnational dimension without corresponding extension of the arm wielding the shield of criminal justice. The AFSJ is profoundly marked by resistance to the notion of proper EU citizenship. The very concept of modern citizenship, however, underlines that this is not a matter in which executives can pick and choose.

Resistance to the encroachment of EU criminal justice matters into constitutional contexts has not been even-handed. As established above, repressive instruments (despite appearances of more technical, everyday criminal justice provision) have not been stopped by their impact upon constitutional law. The required acceptance of the EAW, for example, meant that many accession states were required to enact constitutional change (lifting the ban on extraditing their nationals particularly) to join the EU in 2004. ${ }^{164}$ Member state executives have thus proved far more comfortable with an expansive notion of EU citizenship in certain contexts. Indeed, the notion of the EU citizen is a figure of utility in some settings. ${ }^{165}$ Article 3(2) TEU states that,

The Union shall offer its citizens an area of freedom, security and justice without internal frontiers, in which the free movement of persons is ensured in conjunction with appropriate measures with respect to external border controls, asylum, immigration and the prevention and combating of crime. ${ }^{166}$

Thus, a common definition of substantive offences such as terrorism and human trafficking is framed as necessary to protect EU citizens and their values. Procedural measures such as the EAW are needed to

${ }^{163}$ Stephen Coutts, "The Lisbon Treaty and the Area of Freedom, Security and Justice as an Area of Legal Integration" (2011) 7(7) Croatian Yearbook of European Law \& Policy 87-107, 102.

${ }^{164}$ See Derenčinović, supra note 123.

${ }^{165}$ See, for example, the citizen being addressed in Council Regulation (EU) 2017/ 1939, supra note 146, Preambles 59 and 60.

${ }^{166}$ See, for example, Directive (EU) 2017/541, supra note 108, Preambles 3 and 12; Directive 2011/36/EU, supra note 108, Preambles 1 and 4. 
ensure the four freedoms are not taken advantage of, ultimately leaving the EU citizen unprotected from those who break the rules of this emerging polity. ${ }^{167}$

These needs of EU citizens have been deemed great enough to traverse considerable boundaries (particularly relating to freedom of movement). The victim citizen has been endowed with rights in criminal proceedings at the EU level to ensure procedures work well. ${ }^{168}$ In all of these cases, the EU citizen is not overtly addressed as such, but (at least) since the decision of the Grand Chamber in Pupino $^{169}$ members of the Council have known they are legislating for all citizens of the Union. Increasingly, therefore, the Council, in its expansive use of the AFSJ, must be viewed as serving the EU citizen, even if in an asymmetric manner. The Council's Strategy 2019-24 indeed emphasises 'protecting citizens and freedoms' as one of the four highest priorities of the Union. ${ }^{170}$

The Council has in truth engaged in discussion of the AFSJ's relationship to citizenship from the early days. Some member states have always advanced a more holistic notion of what citizenship should mean in this policy area. The EAW Framework Decision was introduced on the understanding that it would be swiftly followed by legislation securing defence rights in criminal proceedings, precisely because some member states viewed the introduction of such repressive power without the counter-balance of freedom-securing mechanisms as illegitimate. The political consensus to recognize the enormity of what was done (and therewith the kind of re-characterisation EU citizenship underwent upon the introduction of the EAW) simply disappeared when liberty-securing mechanisms were tabled. ${ }^{171}$

${ }^{167}$ Council Framework Decision 2002/584/JHA, supra note 57, Preamble 5.

${ }^{168}$ See Council Directive 2012/29/EU of the European Parliament and of the Council of 25 October 2012 establishing minimum standards on the rights, support and protection of victims of crime, and replacing Council Framework Decision 2001/ 220/JHA, OJ L315; and C-105/03, supra note 84.

${ }^{169} \mathrm{C}-105 / 03$, supra note 84.

${ }^{170} \operatorname{COM}(2019) 353$ Final: Communication from the Commission to the European Parliament, the European Council and the Council - Nineteenth Progress Report towards an Effective and Genuine Security Union, p.1.

${ }^{171}$ In critical criminology, evaluation of the cynical mobilisation of certain figures within criminal justice abound, such as the description of victims as "the restorative face of new punitivism." Note also that the UK Government has opted into the new Eurojust arrangement and ECRIS, despite on-going Brexit negotiations. 
This was reflected also in states opting out of Stockholm Programme measures. ${ }^{172}$

The problem of the EU as a 'policy-laundering' governance level that strengthens national governments and weakens citizens that might be in tension with such governments is clear. The usual checks and balances of national liberal systems have no place within this framework. This is not exclusively a citizenship problem but certainly a cause for citizens to feel betrayed and subjected to illegitimate exercises of power facilitated by the EU. Ultimately this clearly undermines the legitimacy of the EU. Although the Lisbon Treaty amended the Treaties to ensure greater Parliamentary participation (providing the EU Parliament with a legislative role but also making it, alongside national parliaments, ${ }^{173}$ a key means of ensuring accountability) cannot fundamentally change this. The history of justice and home affairs (JHA) as the Third Pillar ensures the executive branch has an enormous head start. Its priorities are already operationalised. Any adaptation of the concept of EU citizenship to truly acknowledge this has yet even to be tabled; any channel via which citizens can voice their citizenship expectations, yet to be created. Furthermore, parliamentary participation is subject to exceptions in relation to criminal justice and the European Parliament is, in any case, not structured to do this task justice. ${ }^{174}$

The problem of policy-laundering becomes obvious when, for example, one regards the various responses to the CJEU's Digital Rights Ireland judgment, contrasting member states' courts with governmental reactions (the UK forms an exception with the Supreme Court, unlike its EU counter-parts, apparently reading the

${ }^{172}$ Juan Santos Vara and Elaine Fahey, "Transatlantic Relations and the Operation of AFSJ Flexibility" in Steven Blockmans (ed.), Differentiated Integration in the EU - From the Inside Looking Out (Brussels: Centre for European Policy Studies, 2014) pp. 103-125.

${ }^{173}$ See Eurojust, Article 85 (1) Consolidated versions of the Treaty on European Union and the Treaty on the Functioning of the European Union (TFEU) [2016] OJ C202/1; and Europol Article 88(2) TFEU.

${ }^{174}$ Sergio Carrera, Nicholas Hernanz, and Joanna Parkin, “The 'Lisbonisation' of the European Parliament: Assessing Progress, Shortcomings and Challenges for Democratic Accountability in the Area of Freedom, Security and Justice." (September 2013) CEPS Paper No. 58, at https://www.ceps.eu/ceps-publications/ lisbonisation-european-parliament-assessing-progress-shortcomings-and-challenges/ 
judgment very narrowly). ${ }^{175}$ The judicature clearly differs greatly from the executive in its understanding and application of fundamental rights. Furthermore, structural issues abound. Even where CJEU judgments come down as a robust defence of principle, as in this case, which clearly highlights the supremacy of privacy and data protection and strengthens proportionality requirements, more practical considerations can be decisive. In that case, the Court's failure to address whether such blanket retention can ever be lawful met only a very muted legislative reaction across the Union. ${ }^{176}$ Some member states' non-compliance (or in the UK's case, apparent contradiction) of the CJEU may be regarded as a power play. Thus, even where the CJEU upholds a principle, its institutional setting may mean that is insufficient to ensure the constitutional nature of citizenship is protected.

AFSJ measures are transporting the EU citizen into spaces where she cannot expect to be treated equally to resident country nationals (e.g. bail hearings). The equal treatment that forms the core of EU citizenship for those who have exercised their freedom of movement rights cannot be applied straightforwardly in the criminal justice context. ${ }^{177}$ The notion that this can be deemed collateral damage of how the EU operates is to deny the constitutional nature of EU citizenship, and would allow member states to utilise the EU for further repressive criminal justice ends, whilst ignoring the constitutional nature of that setting (as established in their domestic systems). The failure to acknowledge the appropriate legal level within which to place such developments has furthermore prevented any consideration of novelty (as would be warranted within the EU Framework). The EU is not merely a super-sized replication of the nation state. The imposition of criminal justice by the EU, or implemented by other systems on its behalf, may be different in nature to national

${ }^{175}$ See Niklas Vainio, Samuli Miettinen, Telecommunications data retention after Digital Rights Ireland: legislative and judicial reactions in the Member States, International Journal of Law and Information Technology, Volume 23, Issue 3, Autumn 2015, pp. 290-309.

176 Niklas Vainio, Fundamental rights compliance and the politics of interpretation, in Tobias Bräutigam and Samuli Miettinen (eds), "Data Protection, Privacy and European Regulation in the Digital Age" (Helsinki, 2016) ; Helsinki Legal Studies Research Paper 46, pp. 229-259.

${ }^{177}$ Kostakopoulou, supra note 52, 430. 
executive organs so doing, because the EU is a governance level in its own right. ${ }^{178}$

The decisive point is that as a result of what has been established in the AFSJ, the EU is now in a fundamentally different position to that when EU citizenship was initially conceived. The EU has become established as a significant criminal justice actor. As a governance level, it exposes citizens to criminal justice practitioners acting as Europeans. This is obvious when, for example, a Europol agent becomes involved. However, the contradictory fiction is often kept alive by preventing European agents from being given a direct role and a nominated national agent or prosecutor (acting upon information conferred by Europol, a JIT or similar) performing investigative and prosecutorial tasks. The EU citizen is served by the Europol agent, but that agent is not manifested as part of the process to ensure the European citizen can hold her accountable for the contribution she has made. A national agent acts as an intermediary and the veneer of a legal fiction. The time has come, however, for the law no longer to accept this veneer or the labels applied to such scenarios by executives. For EU citizenship to be felt in the local, it is necessary that that a local officer benefiting from Europol intelligence) should regard themselves as a European agent, with a duty of care towards every European citizen. Ironically, the double-hat principle invoked to ensure greater national control of the EPPO ${ }^{179}$ provides a model for legal accommodation of precisely the kind of accountability argued for. Currently, EU mechanisms mostly allow practitioners to delegate responsibility for constitutional protections to a foreign colleague (at a later time), rendering citizenship considerations something promised for the future, rather than felt in the actual, current local.

Within member states, the rule of law depends upon executives being unable to divest themselves of their duty of care or constitutional obligations to citizens via false labelling ${ }^{180}$ or outsourcing. ${ }^{181}$

${ }^{178}$ For analysis of specific examples to illustrate this see Wade, supra note 118, p. 165 et seq.

179 Deputy European prosecutors - those actually carrying out investigations and prosecutions - will remain embedded in national systems although paid for by the EPPO. See Articles 13 and 17 of EPPO Regulation, supra note 146.

${ }^{180}$ See ECtHR stance on Article 6, Stefan Trechsel, Human Rights in Criminal Proceedings (Oxford: Oxford University Press, 2006) p.13 et seq.

${ }^{181}$ See e.g. the striking down of a scheme requiring landlords to check nationality/ residency rights of potential tenants with its discriminatory effects - $\mathrm{R} v \mathrm{SoS}$ for Home Department [2019] EWHC 452 (Admin). 
Transferring such notions to the EU level in criminal justice terms means that if punitive powers are transferred to or via the EU level to impact equally upon all EU citizens, they must also be equally protected. Particularly after Melloni ${ }^{182}$ (in which the CJEU affirmed the primacy of EU law, even over national constitutional law providing higher protection), we must ensure this is entirely fit for purpose and demand that the AFSJ serves the EU citizen in her entirety. ${ }^{183}$ Furthermore, effective constitutional protections doubtlessly require specialist mechanisms for political ${ }^{184}$ and legal accountability. ${ }^{185}$ EAW procedures have demonstrated all too clearly that judges remain locked in their national context when it comes to human rights protection, forced to rely upon a colleague in another member state (perhaps to a considerable extent in the future) to ensure the citizenship protections usually embedded in national criminal procedures. If constitutional law is to have meaning and the term 'citizenship' particularly, then the fiction that the EU only adds a layer to pre-existing national structures must be effectively countered.

To declare that the freedoms and mechanisms currently provided by the EU (also within the AFSJ as it stands) cannot be given or used is not in the interests of EU citizens. The EU provides freedoms many citizens cherish and there is much to be said for the more potent cross-border law enforcement mechanisms of the AFSJ. ${ }^{186}$ Such freedoms and powers must, however, be granted and exercised in honest recognition of their nature. Contexts lending expression to

\footnotetext{
${ }^{182}$ Case C-399/11, supra note 76.

183 The fact that this is limited to areas with a direct nexus to EU law (see CJEU cases: C-617/10 Aklagaren v Hans Åkerberg Fransson [2013] EU:C:2013:105; C-42/17 Criminal Proceedings against M.A.S. and M.B. (Taricco) [2017] EU:C:2017:936; C206/13 Cruciano Siragusa v Regione Sicilia - Soprintendenza Beni Culturali e Ambientali di Palermo [2014] EU:C:2014:126) is of no comfort as the EU's remit extends strongly into areas of serious crime and as the competence of its institutions (Europol and Eurojust, nevermind the EPPO) extends.

${ }^{184}$ On the creation of a potential model (developed for Europol) see Valentin Kreilinger, A watchdog for Europe's policemen (2017), Jacques Delors Institute Berlin, Policy Paper 197, 12th June.

${ }^{185}$ The EPPO model currently being made a reality provides considerable cause for concern in this regard.

${ }^{186}$ See National Crime Agency, "National Strategic Assessment of Serious and Organised Crime" (2019) at https://nationalcrimeagency.gov.uk/who-we-are/pub lications/296-national-strategic-assessment-of-serious-organised-crime-2019/file; and Europol, "Serious and Organised Crime Threat Assessment (SOCTA)" at https:// www.europol.europa.eu/socta-report.
} 
constitutional fundamentals cannot be transmitted to the EU level without their constitutional setting also being transferred. ${ }^{187}$ The insistence of a few member states on attempting this (even whilst pushing aggressively for criminal justice measures to punitive ends at the EU level ${ }^{188}$ means these contexts strain the meaning of citizenship more broadly, and EU citizenship in particular. The Treaty of Lisbon undeniably represents enormous legal transformation and brings with it a constitutionalising effect upon the AFSJ. ${ }^{189}$ The problem remains, however, that the citizenship model being advanced is limited. Fundamental principles are only mentioned in preambles or superficially attended to and so cannot be operationalised. Enabling this to happen in the multi-level context of the EU is unquestionably a challenge of herculean proportions. It is, however, one to which attention must be turned. By extending the punitive arm of member states' criminal justice systems via the EU to serve these interests of the EU citizen, the member states have introduced the very heart of traditional citizenship concepts to the EU governance level. They must now also accept the consequences of so doing. ${ }^{190}$

Entering such discussions, one should be cautious not to overromanticise the nation state-based notion of citizenship. It too is highly contested when it comes to the protections afforded to (sus-

${ }^{187}$ For example, the EAW allowing prosecutors across the Union to trigger arrests in any member states, without creating a court able to hear complaints against all aspects of such warrants means only a part of criminal justice mechanisms is facilitated via the EU.

${ }^{188}$ See for example the UK in the counter-terrorism context analysed in Marianne L. Wade, Fighting Terrorism - The Unprincipled Approach in Marianne L. Wade and Amir Maljević, supra note 123.

${ }^{189}$ For a precise analysis see Mitsilegas, supra note 69, p. 9.

190 The Schengen development, for instance, stands as the most obvious demonstration of the futility of trying to separate mercantile activity from security. The fundamental flaw of attempting this was exposed as the smaller group of member states (whose geography perhaps made the matter more pressing) signed the Schengen Accord outside the framework of the EU (because there was insufficient political consensus within the EU) in response to developments within it. Nevertheless, it cannot be denied that the focus of EU activity relates to law enforcement. Notably, no Schengen equivalent has been attempted to secure defence rights provision, for instance. This one-sided concern at EU level stands in clear contrast to the constitutional and human rights provision limiting the reach of executive agencies within national settings. 
pected) criminals. ${ }^{191}$ Tensions at the EU level do not emerge from that context. They are there precisely because they are on-going in the constitutional contexts of member states. This naturally only increases the potential potency of the EU for policy-laundering, with the ability to undermine constitutions. It is ironic that the one-sided criminal justice push gathers such momentum just as the Lisbon Treaty changes directly address the longer-standing criticisms of the EU as lacking democratic basis and legitimacy. It is existentially important to the EU to close such damaging lacuna because the utilisation of this governance level as a policy-laundering arena encourages those seeking to negate its value. Member states must finally be forced to recognise that if they continue to utilise the EU as a means to circumvent their national parliaments and constitutionally established judicial systems, they endanger the EU itself. If those things the Union provides citizens with (and which they in turn value as a basis for their lives) are ultimately insecure or built on an asymmetric rights basis that does not meet reasonable expectations, ${ }^{192}$ this will undermine EU credibility more broadly. That such arguments are mobilised disingenuously by Eurosceptics and the press is not new. However, the Commission's robust rule of law stance makes high-profile conflict inevitable. Rendering EU citizenship fully worthy of the name is thus not only a matter of existential importance to a number of citizens but may well be so for the Union itself.

The EU may not be the creator of problems we encounter in criminal justice processes engaging its procedures and institutions but it does massively increase the reach and impact of such difficulties where its mechanisms are implemented. It cannot be the function of a governance level created to enhance the lives of its citizens to supercharge the disparity and unfairness known to characterise national criminal justice systems. This demands that we confront such problems honestly as a new sovereign is empowered in this sensitive policy area. The EU is a huge geographical area with 24 official languages and 31 legal systems (at the time of writing) and yet no provision has been made for the exercise of executive power across this domain to

${ }^{191}$ See Citizenship deprivation cases discussed supra note 123 , furore over prisoners' voting rights surrounding the case of Greens and MT v UK before the Court of Human Rights (appl. nos 60041/08 and 60054/08 ), etc.

192 On the tension between citizen and member state wishes, see Guild, supra note 28 , p. 422 et seq. 
be coupled with proper consideration of its impact upon the citizen. ${ }^{193}$ This highlights the inadequacy of EU citizenship.

The conventional argument is that the EAW, EIO, etc. are not the EU as a sovereign imposing punishment and there is some truth to this. EU mechanisms are carefully constructed to ensure it is a national criminal justice system carrying out a given activity. The question is, however, whether it is legally correct to accept this label. ${ }^{194}$ There is also truth to the assertion that citizens are only exposed to these mechanisms because they are EU citizens: that national criminal justice practitioners are only acting as they do because the EU legislator has empowered that agent to do so. From a fundamental rights point of view, an EAW is not the same as a national arrest warrant; a JIT, a Europol-supported investigation, is not the same as one governed by a clear set of national procedural laws; a decision being made in Eurojust is not the same as that of a local prosecutor. In comparison, transparency is much reduced and the possibilities of effective appeal are not provided for, as those affected only have recourse to national courts. For a long time, we have insisted that EU citizens must put up with this empowered executive without counter-balancing protective and participatory rights. Particularly now that a genuinely EU criminal justice agency is being created (the EPPO), this position can surely no longer be allowed to stand.

\section{CONCLUSION: THE PRESSING URGENCY OF EU CITI- ZENSHIP FIT FOR PURPOSE}

The very idea of citizenship evokes expectations. Individual citizens expect a facilitative framework within which to live their lives as an active part of the communities that shape their lives. Such expectations are decisive not only in relation to the legal objections lodged by

\footnotetext{
${ }^{193}$ Interestingly Commission Impact Assessments look primarily to financial and more technical impacts, even in the criminal justice realm. See e.g. EPPO impact assessment. European Parliament, "Initial Appraisal of a European Commission Impact Assessment: European Commission Proposal for a Council Regulation on the Establishment of the European Public Prosecutor's Office - Impact Assessment (SWD (2013) 275 final, SWD (2013)274 final (summary)) for a Commission Proposal for a Council Regulation on the Establishment of the European Public Prosecutor's Office (COM (2013) 534 final)" at http://www.europarl.europa.eu/RegData/etudes/ note/join/2013/514087/IPOL-JOIN_NT(2013)514087_EN.pdf.

${ }^{194}$ Article 6 ECHR context makes us aware that this is dangerous, supra note 178.
} 
individuals when they suffer concrete losses due to the deficient nature of EU citizenship as it currently stands: they also affect the understanding of those employees of EU institutions who breathe life into EU law and policy. If they are instructed to serve the EU citizen (even in an act of legislative window-dressing), this will have meaning for such individuals who carry the ideas of citizenship from their own member states. Given the recognised deficiencies of EU citizenship, such expectations simply prime EU legislation for conflict. Where the member states then decide to use EU mechanisms for something as sensitive as criminal justice ends, without ensuring legitimate citizenship expectations are considered, naturally controversial litigation and argument ensues. The member states have clearly elected to mobilise the EU as a governance level for policy matters that necessitate a fleshed-out concept of citizenship to legitimately house them. It is therefore high time due attention is given to the meaning of EU citizenship.

As things stand, it appears eminently reasonable to describe EU citizenship in its current form (particularly when viewed from the AFSJ perspective) as an odd creature. The citizenship to be found in technical legal treatment such as CJEU jurisprudence or specific legislative instruments frequently does not fit with the concept advanced since the Enlightenment. This is worthy of discussion because the legitimacy of EU law is not assessed only by specialist lawyers and the AFSJ draws EU mechanisms into an arena exercising coercive force against citizens. EU citizens themselves have reasonable expectations raised by the concept. ${ }^{195}$ The asymmetrical development of the AFSJ is problematic because vocabulary matters.

Currently the impression is that EU citizenship is malleable ${ }^{196}$ and a matter of technical legal application. Whilst in national settings criminal law is often an expression of what citizenship is, efforts at the EU level have often seen such considerations pushed into the background as executive priorities outweigh everything else within the legislative procedure. This paper argues that this failure to recognise that criminal justice is an area of delicate balance is a key failing for

${ }^{195}$ In parallel to Cryer's assertion concerting international criminal justice, see Robert Cryer, "Royalism and the King: Article 21 of the Rome Statute and the Politics of Sources" (2009) 12(3) New Criminal Law Review 390-405, 391. Such expectations are unlikely to be reduced to the kind of technical legal meaning the CJEU employs in the light of the lacuna discussed above.

${ }^{196}$ See, for example, the discussion of transfer of prisoners in Mancano, supra note 68 , p. 61 et seq. 
the EU governance level. As the ultima ratio of state power, the status quo of criminal justice in European nations has been forged over centuries of history in which the abilities of rulers to punitively intervene in the lives of their subjects was curtailed by movements that brought about modern liberal democracies. Criminal justice and the balance within systems producing it remains a dynamic and controversial policy area. However, all European criminal justice systems contain functions analogous to the sword and the shield. The EU has been criticised for disproportionately advancing the free movement of the sword independent of the shield. As such, the EU can be accused of failing to learn lessons from the US experience, which saw states deliberately utilising Federal law and institutions to undermine state constitutional protections. ${ }^{197}$

It would be grossly unfair not to recognise that EU citizenship has meaning, particularly in areas of law squarely covered by the Treaties; that the constitutionalising process of the Lisbon Treaty is underway (and significant); and indeed that developments like the Charter are of great value and may provide important impetus for change. The same is true of the rule of law interventions the Parliament and Commission are embroiled in at the time of writing. That the AFSJ is operationalised in a grossly asymmetrical fashion remains a formidable deficit, however. The lacuna opened up in criminal justice is not addressed by membership of the European Convention on Human Rights. That mechanism is intended to ensure standards in the national context and is not easily adapted to something like the EU. The EU Charter, of course, contains rights of relevance ${ }^{198}$ and jurisprudence will doubtlessly render these more robust. Nevertheless, the AFSJ is unquestionably a context becoming constitutionalized without any idea of a sovereign punishing citizens at its core. As we have seen, this leaves both it and EU citizens at the mercy of executives.

Fundamentally, citizenship is not a status that can be granted within the limits a sovereign deems appropriate. By its nature, the concept pushes at the boundaries of what an executive finds comfortable. A citizen is an active member of a community, endowed with the right to work to change the remit of her sovereign, to stay the hand of that power, so that she can live her (civically responsible) life within the bounds she chooses. By utilising 'citizenship', the member states have adopted the language of revolution and elevated

\footnotetext{
${ }^{197}$ See e.g. Lisa Miller, The Perils of Federalism (OUP, 2008).

${ }^{198}$ For an overview see Mitsilegas, supra note 69, p. 9.
} 
it to the EU governance level. The concept embodies the idea of the presumed powerless exposing the fallacy of that assumption when executives mobilise against their core interests. The developing, democratising EU language used by parliamentarians (who clearly feel responsible for citizens) reflects this.

With this latest development, the Union as a governance level is also taking robust steps against democratically elected governments to ensure the protection of the rule of law and EU values. ${ }^{199}$ This invariably brings criticism and scrutiny with it. With that in mind, unmet expectations and values betrayed in the context of individual EU mechanisms pose a bigger problem, including for the (legitimacy of the) EU itself and the significance of how it is perceived by a broader audience. The EU, whether represented by the Commission or the Council, cannot insist that the CJEU uphold the Union's values and the lofty ideals of article 2 TEU (Rule of Law) in infringement proceedings against member state governments, without expecting it to uphold them when individual citizens challenge legislative instruments or member states' implementation/operationalisation of them.

If EU citizenship is not transformed into something closer to the core concept, it will become new ground for pessimism within citizenship studies. ${ }^{200}$ If the citizenship provided to member states' citizens within the boundaries of the EU endows them with the freedom to travel but simultaneously allows member states to undercut the constitutional protections their polity has established within criminal justice structures, citizens will perceive it as negative. If the EU presents itself as providing the right to move freely but, for example, does not protect families that result from the exercise of that freedom, the value of what it offers will be considerably diminished in the eyes of its citizens. Doubtlessly this is a politically sensitive area. However, if the TEU speaks of the EU being founded upon 'the values of respect for human dignity, freedom, democracy, equality, the rule of law and respect for human rights' and the CJEU intends to ensure 'full enjoyment of rights', then EU citizens will understandably expect their EU citizenship to protect them. The rule of law demands that their expectations be attended to.

${ }^{199}$ As outlined in the TEU.

${ }^{200}$ See Engin F. Isin and Peter Nyers, "Introduction: Globalizing Citizenship Studies" in Isin and Nyers, supra note 14, p. 5; Teresa Pullan, "How European Citizenship Produces a Differential Political Space" in Isin and Nyers, supra note 14, p. 437, utilising Derrida (Spectres of Marx). 
The time of EU citizenship as "democracy to come" 201 is therefore surely over? If the criminal justice successes achieved ${ }^{202}$ are to remain sustainable, they must be housed in an appropriate constitutional setting, ensuring the fundamental tenets of criminal justice are adhered to and therewith their legitimacy secured. In short, EU citizenship must deliver the meaning it promises. What precisely it promises and citizens can legitimately expect must doubtlessly be clarified via extensive political dialogue including citizens. Such discussion is long overdue.

This paper highlights the need to also place EU criminal justice developments at the heart of structured considerations of Union citizenship and vica versa. It seeks to build a bridge between the citizenship studies it draws upon, highlighting their value to the EU criminal justice scholarship it seeks to further thereby undertaking a first academic step of the kind of discussion EU citizenship requires. Only such an integrated approach can truly contribute to meeting the reasonable expectations of citizens; the goal we all pursue. The sword of criminal justice has been pressed into the hands of the EU. The agents wielding it may look a bit odd, ungainly and unwieldy, but from the perspective of citizens, wield the sword they do. Meaningful citizenship in the European tradition (drawing inspiration from the constitutional traditions common to the Member States, ${ }^{203}$ ) demands an equivalent shield. How precisely this should be formed is doubtlessly still a matter for extensive, and controversial, debate. Nevertheless, citizenship demands it.

\section{OPEN ACCESS}

This article is licensed under a Creative Commons Attribution 4.0 International License, which permits use, sharing, adaptation, distribution and reproduction in any medium or format, as long as you

201 The EAW has clearly become an important mechanism member states do not want to be without - see Report from the Commission to the European Parliament and The Council (2011) on the implementation since 2007 of the Council Framework Decision of 13 June 2002 on the European arrest warrant and the surrender procedures between Member States $\{\operatorname{SEC}(2011) 430$ final\}.

${ }^{202}$ Supra note 199; and House of Commons Home Affairs Committee, "PreLisbon Treaty EU police and criminal justice measures: the UK's opt-in decision" (TSO, 2013) 9th Report 2013-2014, pp. 5-16.

${ }^{203}$ As per the ECJ in Kadi supra 61. 
give appropriate credit to the original author(s) and the source, provide a link to the Creative Commons licence, and indicate if changes were made. The images or other third party material in this article are included in the article's Creative Commons licence, unless indicated otherwise in a credit line to the material. If material is not included in the article's Creative Commons licence and your intended use is not permitted by statutory regulation or exceeds the permitted use, you will need to obtain permission directly from the copyright holder. To view a copy of this licence, visit http://creativecommons. org/licenses/by/4.0/.

Publisher's Note Springer Nature remains neutral with regard to jurisdictional claims in published maps and institutional affiliations. 